\title{
Provoking Residential Demand Response Through Variable Electricity Tariffs - A Model-Based Assessment for Municipal Energy Utilities
}

\author{
Fabian Scheller $^{1}$ (D) . Jonas Krone ${ }^{1} \cdot$ Stefan Kühne ${ }^{2} \cdot$ Thomas Bruckner $^{1}$ \\ Received: 5 February 2018 / Accepted: 17 May 2018 / Published online: 4 June 2018 \\ (C) Springer Nature Singapore Pte Ltd. 2018
}

\begin{abstract}
With the suitable infrastructure of information and communication technologies in place, customers are able to perform demand response (DR), meaning that they can decrease or increase their electricity consumption in response to changes in their electricity tariff. In this research, different variable electricity tariffs are designed taking both customer and utility preferences into account. Subsequently, a model-based analysis on the basis of optimization model IRPopt (Integrated Resource Planning and Optimization) is carried out. Electricity customers are exposed to the designed tariffs in order to find out whether variable electricity tariffs are a suitable instrument for municipal energy utilities to exploit the potential laying in residential DR. Loads considered for DR in this work are those of selected electric household appliances and the loads of electric heat pumps. One major contribution of this work is that the assessment differentiates between different types of energy utilities, whose specific generation profiles are taken into account in the design of the variable tariffs. The results show that variable electricity tariffs have a small economic potential. However, customers only benefit if the design of the business model includes a proper compensation mechanism. In this context, successful business models require the direct cooperation of different municipal energy market actors. Furthermore, taking the specific generation profiles of municipal energy utilities into account in the design of variable electricity tariffs helps to increase the energy autonomy of municipalities.
\end{abstract}

Keywords Demand response · Variable tariffs · On-site business models · Decentralized energy systems · Energy system optimization

\section{Introduction remarks}

\section{Motivation}

The transformation of the German energy system must be seen in the context of the significant changes that have been taking place in the European electricity sector during the last two decades. Among these changes are the liberalization of electricity production, wholesale trade and distribution markets for end customers [44]. Additionally, the unbundling of the market segments of sales and distribution set new rules regarding price design and market access. The

Fabian Scheller

scheller@wifa.uni-leipzig.de

1 Institute for Infrastructure and Resources Management, Leipzig University, Leipzig, Germany

2 University Computing Center, Leipzig University, Leipzig, Germany introduction of a feed-in tariff scheme for electricity produced by renewable energy sources enhanced the competitiveness of renewable energy sources [44].

While these changes have accompanied the muchnoticed Energiewende (energy transition) in Germany, they are also putting immense pressure on energy utilities. The growing share of electricity production from renewable energy sources has led to a considerable decrease of electricity prices and consequently, to an erosion of energy utilities' revenues [32, 38]. So far, energy utilities have failed to find a suitable response to these developments in the form of innovative business models. However, municipal energy utilities are especially able to play an important role in the transition of the energy system due to their decentralized nature, their infrastructure, their close relationship with customers and their strong interconnections with the municipality [15].

It will no longer be profitable for energy utilities to act according to the old paradigm supply follows demand in an energy system relying more and more on predominantly uncontrollable renewable energy sources [16]. The proposed alternative for the future - a supply and demand 
that complement one another - requires flexible consumers to adapt their demand by providing demand response (DR) [16], meaning that they decrease or increase their electricity demand according to the supply.

While the DR potential of energy-intensive industries is already being exploited, the DR potential of household customers is still lying dormant [16]. Simultaneous, recent developments in the field of electricity metering offer the chance to exploit the residential DR potential. Without any doubt, smart meters are essential to create the "flexible consumer" [5]. Additionally, in order to make any use of the residential DR potential, the load flexibilities of a large number of residential customers need to be aggregated. The fact that active DR is ultimately mediated by contracts with consumers qualifies energy utilities, particularly, municipal energy utilities for the role of flexibility aggregator [21]. One way energy utilities can give consumers the incentive for providing DR is via variable electricity tariffs.

In view of the key question "Are variable electricity tariffs a suitable instrument for municipal energy utilities to exploit the economic and environmental potential laying in residential DR?", the objective of this work is to analyze the business potential and the implications for energy utilities offering variable electricity tariffs to residential customers. In order to quantify the effects, a model-based analysis on the basis of the techno-economic optimization model IRPopt (Integrated Resource Planning and Optimization) [33-35] is carried out. For a systematic processing, the research intends to accomplish the following sub-questions:

- What residential customer preferences are present with respect to the DR implementation on the basis of different variable electricity tariffs?

- How does the implementation of DR impact the targets of the provider and customer and what effects are noticeable with respect to the variable tariffs?

- What implications can be derived with respect to DR implementation at different energy system conditions as utility and customer types?

The research paper is organized as follows: "Demand Response" gives an introduction to the fundamental theoretical concepts of DR in general and of residential DR in particular. Subsequently, "Related Work" provides an overview of the state-of-the-art in the field of residential DR modeling. The developed design of the applied energy system model is outlined in "Optimization Approach", before "Case Studies" defines the system configurations and the input data. The following "Optimization Results" presents the results of the model-based analysis. "Business Implications" draws recommendations and states research limitations. Finally, "Concluding Remarks" summarizes results and outlines future research.

\section{Demand Response}

\section{Model Definition}

In this work, DR is defined "as the changes in electricity usage by end-use customers from their normal consumption patterns in response to changes in the price of electricity over time" [1]. The changes in the price can be described in more detail with hourly or daily or seasonal variable tariffs. According to [40], load curtailment and load shifting are two strategies that customers can adopt to change their consumption behavior. In this sense, DR can be seen as similar opportunity as the battery energy storage for densely populated urban areas as discussed in [23].

Through load shifting, temporary load reductions are compensated for by load increases in other time periods, while load reductions are not balanced out in load curtailment. Naturally, both strategies of consumption change lead to some sort of constraint on customer comfort. The goal of this research is to minimize the comfort constraints for residential customers originating from DR as far as possible. Hence, in this work, it is assumed that residential DR is accomplished exclusively via load shifting, the strategy with the lower constraint on customer comfort.

\section{Program Classification}

Following [1], programs with the goal to motivate end-use customers to provide DR can be classified into two main categories: price-based and incentive-based programs, the latter of which can further be subdivided into classical and market-based programs. This classification is illustrated in Fig. 1, along with examples for the different DR program types.

In direct load control programs, program participants grant the right to control their energy consumption to a load scheduler [16]. To establish the contract between the two parties, the extent to which the load scheduler is allowed to control the contracted loads needs to be determined [16]. This leads to a loss of autonomy for end-use customers due to the disclosure of personal information [21]. In the marketbased emergency DR programs, participants are provided with incentive payments for load reductions during periods of reserve shortfalls [43]. In capacity market programs, customers commit to providing load reductions of a prespecified amount to replace conventional generation [43].

The focus of this work lies on price-based DR programs in which changes in the electricity price over time are transmitted to residential customers via variable electricity tariffs that fluctuate following the real-time wholesale electricity price or rather the prevailing spot market prices [1] (at least to some extent). Price-based programs can be further subdivided into time-of-use pricing and dynamic 
Fig. 1 Demand response program classification, adapted from [1]

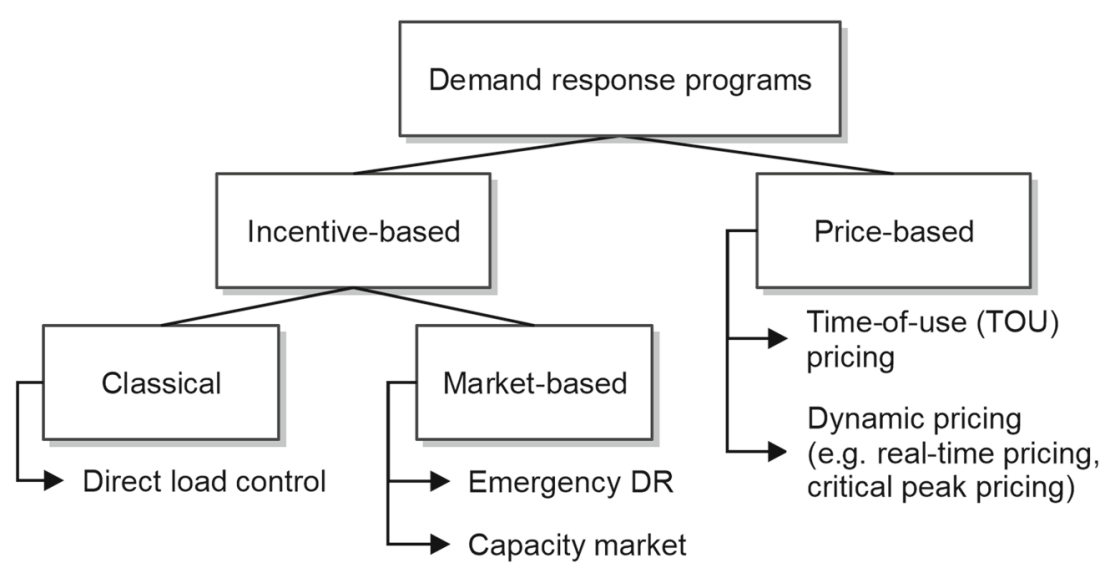

pricing options, of which the latter represents the more flexible tariff design option.

In dynamic pricing (dyn) contracts, the hourly electricity tariff is fixed at short notice and reflects the spot market prices [21]. One example for dynamic pricing is real-time pricing (RTP) for which price information is either provided one day ahead for the next 24 hours or, making RTP fully live up to its name, constantly on an hourly basis [13]. In contrast to RTP, in critical peak pricing schemes the price levels are known to the customers in advance. However, the information about when these price levels are effective is given to the customers at short notice [13]. This tariff option gives utilities the chance to raise a critical peak price, which is significantly higher than the average electricity price, in times of extreme stress on the network [13].

In time-of-use (TOU) tariffs, the day is subdivided into different intervals with constant price levels [13]. Typically, the intervals are determined at the start of the contract. The price levels within these time periods are established on the basis of historical or forecasted electricity spot market prices. Naturally, TOU tariffs are characterized by higher electricity prices during periods of high demand and lower prices during periods with low demand [1]. Seasonal price fluctuations and inherent variations of prices between days - for example between weekdays, Saturdays and Sundays can be accounted for in TOU tariffs.

\section{Pricing Preferences}

In order to minimize their price risk, which originates from the volatility of electricity wholesale market prices, and to optimize their portfolio management (in case own generation facilities are operated), it can be argued that energy utilities prefer highly dynamic tariffs [14].

By contrast, the preferences of energy customers are more complex. The results of an acceptance study, performed by [13], show that customers prefer simple over complex variable electricity tariffs, which are characterized by a rather low dynamic (for example fixed tariff zones
(TZ) with fixed price levels instead of hourly fluctuating prices without predetermined price levels) and a low price spread between low and high price periods. However, [13] did not take for granted that household appliances perform DR automatically.

In this work, it is argued that automatic control of household appliances, leading to almost no perceived discomfort for customers, will make dynamic variable electricity tariffs more attractive to customers. It is necessary that energy utilities complement the introduction of more dynamic electricity tariffs with information on their advantages over the common flat tariff (FT) from an energy market and an individual perspective [13].

\section{Shifting Potential}

Table 1 shows the characteristics of the three groups of household appliances with the ability to perform DR that are considered in this work.

In contrast to the group of base load appliances, semiautomatically controlled appliances do not require constant, but only sporadic user interaction, for example a washing machine needs to be loaded by the customer, but can turn on whenever it is most suitable [16]. This makes this group of appliances usable for DR. Both shifting distance of loads and discomfort connected to load shifts from semi-automatically controlled appliances can be classified as medium. While washing machines and tumble dryers exhibit a load shift horizon of up to 4 hours, loads of dishwashers can be shifted over 12 hours [42]. However, there are some negative repercussions for the customers when using appliances of this kind for DR. For instance, in the case of a DR capable washing machine, customers do not exactly know the time at which the washing process is finished and after which they can take their clothes out for drying. Hence, it is debatable, to what extend the loads of such devices can be considered as shiftable. To account for the consumer discomforts connected with DR of semiautomatically controlled appliances, it is assumed that a 
Table 1 Characterization of household appliance groups, adapted from [16]

\begin{tabular}{|c|c|c|c|c|}
\hline Appliance group & Examples & Control mode & Shifting distance & Discomfort \\
\hline User interaction & Dishwasher, washing machine, tumble dryer & Semi-automatic & Medium & Medium \\
\hline Cooling & Refrigerator, freezer & Automatic & Low & Low \\
\hline Heating \& hot water provision & Electric heating system (with buffer storage) & Automatic & High & Low \\
\hline
\end{tabular}

maximum of $50 \%$ of loads from this appliance group can be shifted.

All of the appliances of the other two groups can be controlled automatically. Consequently, load shifts by these appliances only lead to minor to no perceived discomfort of end-use customers. However, the shifting distance of cooling devices is limited by the length of their cooling cycle, a parameter that depends, in turn, on the quality of their insulation. Consequently, the length of load shifts of cooling devices is only 0.5 to 2 hours [25]. Compared to that, loads from electric heating systems, responsible for the provision of heat and hot water, can be shifted over much longer time periods, depending on the quality of insulation of the built-in thermal buffer storage. It should be noted that in this work, an electric heating system is defined as an electric heat pump system that is coupled with a thermal buffer storage providing heat and hot water to end-use customers.

In order to get an impression of the share of total load that can be shifted by household customers, the appliances of the three selected appliance groups need to be characterized in more detail. Of particular importance are their consumption share and their penetration level, which defines the percentage of households that are equipped with a certain appliance. An overview of this detailed characterization of household appliances is given in Table 2. Excluding electric

Table 2 Specification of household appliances suitable for DR, adapted from [19]

\begin{tabular}{lccl}
\hline Appliance & $\begin{array}{l}\text { Penetration } \\
\text { level }(\%)\end{array}$ & $\begin{array}{l}\text { Consumption } \\
\text { share }^{\mathrm{a}}(\%)\end{array}$ & $\begin{array}{l}\text { Control } \\
\text { mode }\end{array}$ \\
\hline Refrigerator & $100.0^{\mathrm{b}}$ & $8.3^{\mathrm{c}}$ & Automatic \\
Freezer & $50.3^{\mathrm{b}}$ & $11.3^{\mathrm{c}}$ & Automatic \\
Dishwasher & $69.8^{\mathrm{b}}$ & $6.9^{\mathrm{c}}$ & Semi-automatic \\
Washing machine & $96.2^{\mathrm{b}}$ & $4.5^{\mathrm{c}}$ & Semi-automatic \\
Tumble dryer & $41.1^{\mathrm{b}}$ & $7.5^{\mathrm{c}}$ & Semi-automatic \\
Electric heating system & 5.0 & 49.0 & Automatic \\
\hline
\end{tabular}

a The consumption share of the appliances is calculated with respect to a total electricity consumption of $3500 \mathrm{kWh}_{\mathrm{el}}$. Only the share of the electric heating system is determined with respect to a considerably higher overall electricity consumption of $6900 \mathrm{kWh}_{\mathrm{el}}$ (of which $3400 \mathrm{kWh}_{\mathrm{el}}$ of electricity is used for heating and hot water provision)

Sources: ${ }^{b}[12],{ }^{c}[10]$ heating, flexible household appliances are responsible for up to $38.5 \%$ of the overall residential electricity consumption. However, as aforementioned, shifting loads of semi-automatically controlled appliances is associated with a considerable level of discomfort for the customers. Hence, it is safe to assume that loads from these appliances will not be shifted completely, even if households owning one or more of these appliances meet all the technical requirements necessary for performing DR.

It is assumed that a maximum of $50 \%$ of loads from semi-automatically controlled appliances can be shifted. Taking this into account, the realistic maximum share of shiftable load in households without electric heating system can be estimated to be about $30 \%$ of their total electricity consumption. Not surprisingly, households, whose heating is provided via electric heating systems with thermal buffer storage exhibit a much higher share of flexible electricity consumption.

\section{Related Work}

An overview of the presented literature on residential DR modeling is displayed in Table 3. The review shows that:

- flexible loads are in most cases optimized with regard to the electricity market, in fewer cases also with regard to the reserve market.

- appliances for electric heating and hot water supply are among the most promising devices for demand response, apart from electric vehicles, which are named as a favorable option for the future.

This research deploys a scenario-based analysis at the municipal energy utility scale to assess the present and future potential of residential DR for municipal energy utilities with regard to economic benefits as well as energy autonomy. It aims to analyze the benefits of electricity market optimization to gain a profound insight into the overall potential of residential DR for customers and utilities. Shiftable loads included in the applied model are the electric loads of household cooling appliances and semiautomatically controlled devices representing commonplace household appliances with high penetration levels on the one hand and the loads of electric heat pumps in combination with a thermal storage system on the other. The 
Table 3 State-of-the-art literature of residential demand response modeling

\begin{tabular}{|c|c|c|c|c|}
\hline Publication author & Optimization objective & Model core & Model formulation & DR program \\
\hline [37] & $\begin{array}{l}\text { Customer electricity cost } \\
\text { reduction }\end{array}$ & Electricity market & $\begin{array}{l}\text { Stochastic combinatorial } \\
\text { optimization model }\end{array}$ & Real-time pricing \\
\hline [39] & $\begin{array}{l}\text { Customer electricity cost } \\
\text { minimization }\end{array}$ & Electricity market & $\begin{array}{l}\text { Mixed integer nonlinear } \\
\text { optimization model }\end{array}$ & Time-of use pricing \\
\hline [3] & $\begin{array}{l}\text { Customer electricity cost } \\
\text { minimization }\end{array}$ & Electricity market & $\begin{array}{l}\text { Medium-grained stochastic } \\
\text { hybrid model }\end{array}$ & Direct load control \\
\hline [4] & $\begin{array}{l}\text { Customer electricity cost } \\
\text { minimization }\end{array}$ & Electricity market & $\begin{array}{l}\text { Mixed integer nonlinear } \\
\text { optimization model }\end{array}$ & Dynamic pricing \\
\hline [19] & $\begin{array}{l}\text { Aggregator's generation cost } \\
\text { minimization }\end{array}$ & Electricity market & $\begin{array}{l}\text { Mixed integer linear } \\
\text { optimization model }\end{array}$ & Direct load control \\
\hline [16] & $\begin{array}{l}\text { Minimization of utilities' } \\
\text { generation costs/ Customer } \\
\text { electricity cost minimization }\end{array}$ & Electricity market & $\begin{array}{l}\text { Mixed integer linear } \\
\text { optimization model }\end{array}$ & Direct load control \\
\hline [31] & $\begin{array}{l}\text { Customer electricity cost } \\
\text { minimization }\end{array}$ & Electricity market & $\begin{array}{l}\text { Mixed integer linear } \\
\text { optimization model }\end{array}$ & Real-time pricing \\
\hline [24] & $\begin{array}{l}\text { Customer electricity cost } \\
\text { minimization }\end{array}$ & $\begin{array}{l}\text { Electricity market/ } \\
\text { Balancing market }\end{array}$ & Linear optimization model & Real-time pricing \\
\hline [2] & $\begin{array}{l}\text { Customer electricity cost } \\
\text { minimization }\end{array}$ & $\begin{array}{l}\text { Electricity market/ } \\
\text { Balancing market }\end{array}$ & Linear optimization model & Real-time pricing \\
\hline [26] & $\begin{array}{l}\text { Customer electricity cost } \\
\text { minimization }\end{array}$ & $\begin{array}{l}\text { Electricity market/ } \\
\text { Balancing market }\end{array}$ & $\begin{array}{l}\text { Agent-based demand-side } \\
\text { model/ Mixed integer } \\
\text { linear stochastic supply-side } \\
\text { optimization model }\end{array}$ & Real-time pricing \\
\hline [11] & $\begin{array}{l}\text { Operational cost } \\
\text { minimization of district } \\
\text { heating system }\end{array}$ & Electricity market & $\begin{array}{l}\text { Mixed integer linear } \\
\text { optimization model }\end{array}$ & Real-time pricing \\
\hline
\end{tabular}

main original contributions of this research with regard to the cited literature can be summarized as follows:

- application of multi-level dispatch strategy to determine actor-related optimal results. Technology processes of operator and of user sides are optimally controlled and scheduled with an economic objective under peak shifting constraints. Multiple actors along the energy value chain might assess challenges and opportunities from different perspectives and various interest criteria, since every single consumer and operator has a differing technology-mediated relationship. The multi-level dispatch strategy integrates the different interests of different parties and thus might lead to benefits for both, the organization- and the customer as initially shown by [30], - assessment of the potential laying in residential DR at community scale, differentiating between three different types of energy utilities, which are characterized by distinct generation portfolios. In this research the focus lies low-priced orchestrator (LO), green municipal utility (GMU) and conventional municipal utility (CMU) as introduced by [44],
- design of variable electricity tariffs (time of use and dynamic pricing), balancing both customer and utility preferences. As introduced residential customers and energy utilities have different preferences and requirements when it comes to variable electricity tariffs. In this context, it is necessary that energy utilities complement the introduction of more dynamic electricity tariffs with information on their advantages over the common FT from an energy market and an individual perspective [13].

\section{Optimization Approach}

\section{Integrated Modeling}

The optimal matching of the energy flows between energy sources and energy demand is determined using the model IRPopt [33, 35]. This bottom-up techno-economic numerical optimization model, implemented in GAMS/CPLEX, allows for solving mixed-integer problems (MIP) in a 
quarter-hourly resolution for perennial periods. The model framework mainly expands on different building blocks of the deeco model $[7,8]$, the xeona model $[29,30]$ and the EnergyHub model $[17,18]$. The implemented modular model structure enables the configuration of actors, components, connections and transactions under uncertain market developments and undetermined policy interventions if deemed important to the problem at hand.

Parametrization of the model takes place through the configuration of an energy network graph as well as several financial network graphs. An illustrative schematic overview is illustrated in Fig. 2. More detailed information are given in $[33,35]$. The structural composition of the technical energy system demonstrates the interconnection of the spatially distributed technology processes within a complex societal framework. Since the system comprises several energy sectors, the technical system graph resembles a directed multi-commodity flow network with nodes as engineering components and arcs as flow gateways. The required specification of the technological component nodes is process-dependent. From this perspective, nodes in this research paper are representing energy generation or conversion units, storage technologies as well as energy markets. Thereby, energy markets as well as generation technologies but at some points in time also storage units represent sources of a specific commodity within the flow network. On the time, conversion technologies and demand loads constitute sinks of a certain commodity associated with the sector. An edge in the graph is associated with the energy flow capability between two components, and is thus a single-commodity edge.

Each flow gateway needs to be associated with legal contracts, covering for instance connection and supply or market participation. The system coordination facilitates the commercial interactions between defined market actors and thus represents the financial network graph of the system. Legal contracts at different gateways determine relationships between various actors which are fundamental for operational decisions. They define the exchange of monetary units between actors. The perceived value of their decision depends on the objective function.

The integration of the technical and financial systems is based on the concept of property. In this context, a component sovereignty function indicates which actor has the authority to optimize the engineering component of the energy system model or in other words, the operational management over the optimization variable. The described construct allows the system model to optimize the unit commitment problem from selected actor perspectives by taking into account technical and commercial interactions.

In this sense, the sketched optimization framework builds upon the DEECO model [8] and Energy Hub model [17].

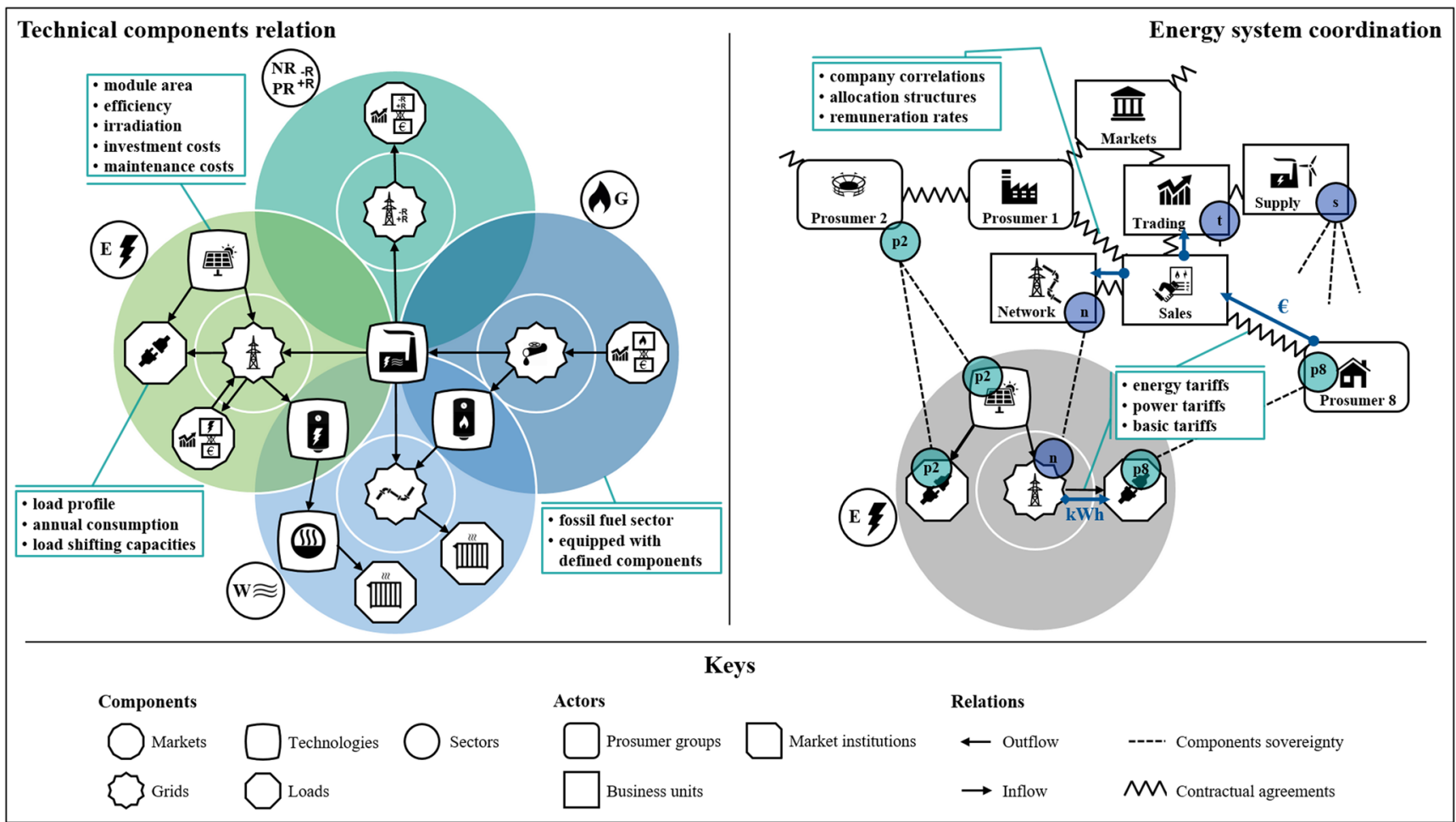

Fig. 2 Schematic representation of the interrelations of IRPopt. The energy network graph (left) as well as the actor dependent financial network graphs (right) form the fundamental basis of the multi-step optimization systematic 
The process formulations of technologies are based on $[8,9,28,45]$. Furthermore, the idea of a multi-level entity oriented optimization approach has been already presented by the authors of the XEONA model $[29,30]$.

\section{Optimization Systematic}

Based on the design decisions, the MIP is modeled through an objective function taking into account the financial flows of chosen market actors, time points and energy sectors, based on the dispatch energy flows of the engineering components. The major objective is to maximize the total profit of individual actors.

In the framework of this paper, the model works with an actor-related multi-step optimization systematic $[29,30]$. The model first optimizes from an aggregated customer perspective, determining the residual energy demand and excess energy supply with all components the customers have regulative access to. With respect to the first optimization step (customer optimization), the tariff scheme is of primary importance. The objective function consists of the sum of the electricity and thermal energy purchase costs from the grid as well as the income from energy grid feed in.

In the subsequent step, the model optimizes all other energy and financial flows from the utilities' perspective, considering all residual energy demand and supply. A regional energy deficit might be balanced by generation plant activities and spot market trading. Excess energy is sold or stored. With respect to the second optimization step (organization optimization), the market prices as well as the variable costs of the energy systems are most decisive. In this context, the objective function is restricted by different equality and inequality constraints. These are derived from processes given by the nature of the components. The objective function consists of the sum out of the fuel costs, the electricity energy costs from the market as well as the sales revenues of electricity energy at the market and the sales revenues of electricity and thermal energy to the end customers.

The two-step optimization process is reflected in the operation strategy of the analyzed system as follows:

- customers, able to perform DR, optimize their electricity consumption with regard to their (variable) tariff scheme

- subsequently, utilities provide the electricity demanded by their customers, minimizing their provisioning costs

By summing up variable and fixed cash flows, IRPopt determines the net present value of payment series of individual customer groups as well as business divisions of utilities.

\section{Shifting Mechanism}

To investigate the business potential of residential DR for energy utilities in a model-based analysis requires the existence of a suitable residential DR representation in the applied energy system model. To a large part the DR formulation builds on the work of [45], which is outlined in the following section, along with the adaptations made to their proposal for this work. The mathematical formulation is outlined in Eqs. 1-4:

$$
\begin{array}{lc}
D R_{t}^{u p}=\sum_{t t=t-L}^{t+L} D R_{t, t t}^{d o} & \forall t \\
D R_{t}^{u p} \leq C^{u p} & \forall t \\
\sum_{t=t t-L}^{t t+L} D R_{t, t t}^{d o} \leq C^{d o} & \forall t t \\
D R_{t t}^{u p}+\sum_{t=t t-L}^{t t+L} D R_{t, t t}^{d o} \leq \max \left\{C^{u p}, C^{d o}\right\} & \forall t t
\end{array}
$$

The positive variables $D R_{t}^{u p}$ and $D R_{t, t t}^{d o}$ are introduced. They represent hourly load shifts in an upward or downward direction. $D R_{t, t t}^{d o}$ represents downward load shifts effective in hour $t t$ to compensate for upward shifts in hour $t$. This formulation directly tags downward load shifts to the respective upward shifts. From Eq. 1 it follows that every upward load shift is compensated by according downward shifts in due time, taking place either before or after the upward load shift, or both. $L$ represents the load shift horizon. It defines in which interval around hour $t$ downward (upward) load shifts must be compensated by upward (downward) load shifts. Equations 2-3 restrict maximum hourly upward and downward shifts to the predefined levels $C^{u p}$ and $C^{d o}$. Depending on which of the restrictions given in these two equations is tighter, only one of the equations is relevant due to equal constraint in Eq. 1 . The other constraint then simply results from Eq. 4. E.g, in case $C^{d o} \leq C^{u p}$, Eq. 2 contains redundant information and can be ignored. On the basis of Eq. 4 the DR capacity is not fully utilized in both directions at the same time.

The actual implications of the proposal by [45] can be shown by drawing on a stylized example. In this example, customers are equipped with DR resources that are characterized by a load shift horizon $L$ of two hours and a maximum level of hourly upward and downward shifts $C^{u p}$ and $C^{d o}$ of $20 \mathrm{MWh}$. The demand without the utilization of DR is constant and the electricity price between the hours 8 to 16 is assumed to be lower than it is during the rest of the day. An illustrative sketch of the example with a DR representation according to Eqs. 1-4 is shown in Fig. 3. Demand is shifted as a reaction to the price signal, with 
Fig. 3 Illustration of the DR mechanism as reaction to a price signal, based on [45]

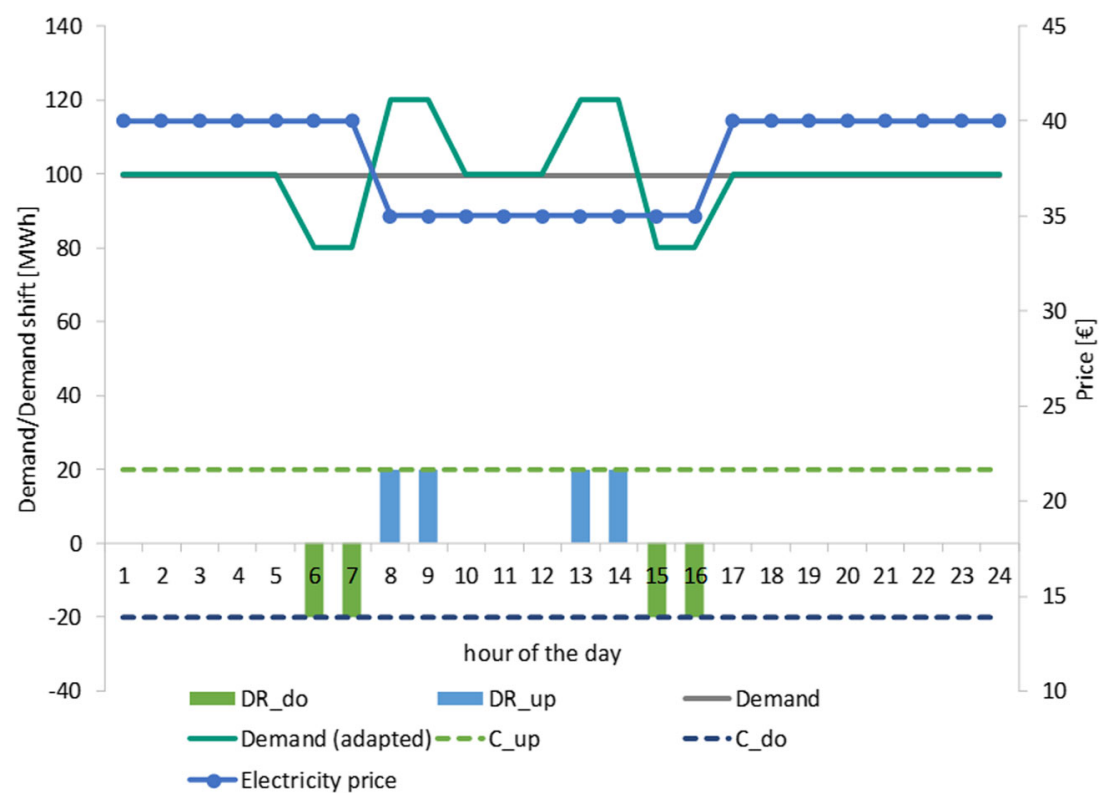

upward shifts in hours 8, 9, 13 and 14 and downward shifts in hours 6, 7, 15 and 16 .

The integration of a DR representation into the existing IRPopt model requires both reinterpretation and adaptation of the presented DR formulation:

- Since IRPopt has a quarter-hourly resolution, the indices $t$ and $t t$ do not represent the hour, but the quarter hour, in which a load shift takes place.

- Due to the rolling horizon applied in IRPopt, the formulation is adapted so that the optimization of residential customers with the help of DR measures is restricted to the optimization horizon. Thus, all load shifts have to be balanced out at the end of every day.

- The DR parameters $C^{u p}$ and $C^{d o}$ are redefined as being load-dependent ( $C^{u p}$ (Customer load up) and $C^{d o}(C$ ustomer load down)). Thus, both parameters can be defined as percentage shares of variable customer loads that serve as input into IRPopt.

\section{Case Studies}

\section{Model Inputs}

\section{Market Foundations}

The potential future state of the energy system is investigated by applying a green scenario, where a strong increase of renewables is assumed. The selected scenario set some of the boundary conditions for the assessment. The quarter-hourly data sets are based on German spot market price projections of MICOES-Europe [6, 20]. In addition to the projections for 2025 and 2035, the initial year of 2015 uses historical market data. An overview of average spot market price characteristics is given in Fig. 4. In this context, the higher projected spot market prices are characterized by a rise of $\mathrm{CO}_{2}$ prices as well as fuel prices. At the same time, the future merit order effect is visible by the through deep valleys. Additionally, an interest rate of $4 \%$ and a value added tax of $19 \%$ is applied.

\section{Relevant Actors}

According to [44], four different types of energy utilities with distinct value-added architectures can be distinguished: supra-regional and local (municipal) integrators, as well as low-priced and green orchestrators. Based on that, this research paper distinguishes on the utility side between three different types of energy utilities. Firstly, a low-priced orchestrator (LO) without any own generation facilities. Secondly, a green municipal utility (GMU), which is characterized by a large share of electricity production from wind energy plants. Thirdly, a conventional municipal utility, whose generation relies largely on cogeneration plants (CMU).

The residential customers considered in this research paper can be distinguished by the share of total electricity consumption that they are able to shift over time. For matters of simplification, none of the residential customers under consideration owns a generation facility. The share of total residential electricity consumption shiftable over time depends on the characteristics of appliances owned by residential customers. Thereby, two customer groups are taken into account with respect to the optimization cases as shown in more detail in Section 2. While in several cases as shown in only a group of five residential customers 
Fig. 4 Average week of spot market prices for the years 2015 , 2025 and 2035 (green scenario)

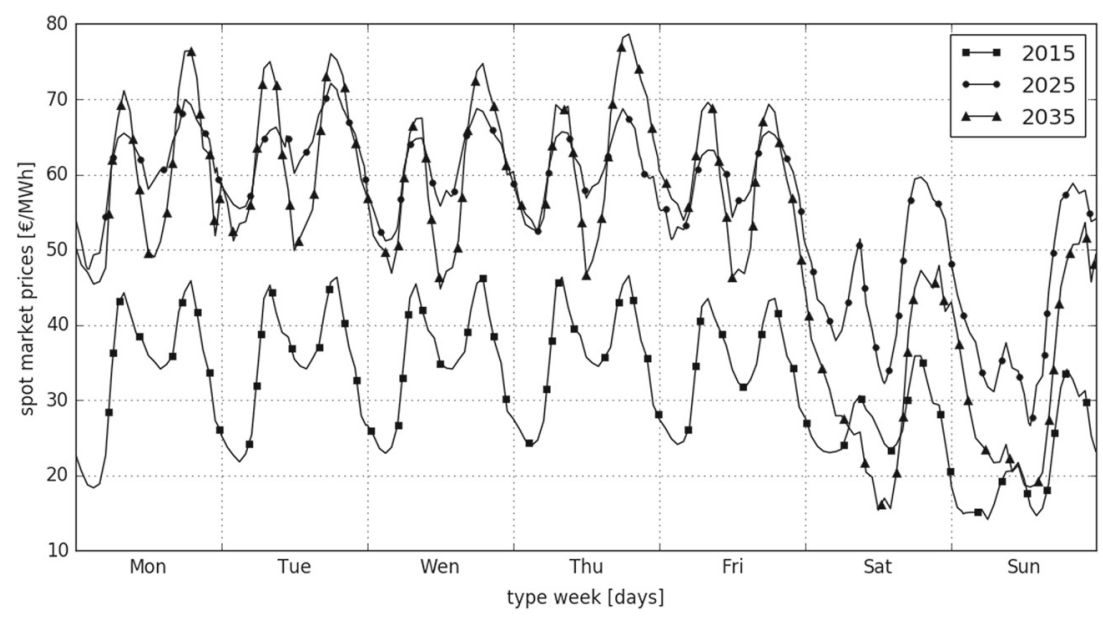

with distinct electrical load profiles is included (customer group 1 - hereafter abbreviated by CG1), in further cases this group is complemented with a customer group of five distinct types of customers characterized by the same electrical load profiles as their counterparts in CG1 and an additional electricity consumption for the provision of heat and hot water by a system coupling an electrical heat pump with a thermal buffer storage (customer group 2 - hereafter abbreviated by CG2).

\section{Electricity Tariffs}

The grid electricity FT is one of the most crucial input data. For every time step in 2015, the customer pays 28.81 $\mathrm{Ct} / \mathrm{kWh}_{\mathrm{el}}$ (el for electrical energy) to sales side, grid side and political side, with proportions depending on fees and levies. Table 4 shows the total cost of electricity and its cost components for household customers purchasing their electricity from the electricity grid in 2015. A detailed analysis is outlined in [36] . After deduction of the statutory

Table 4 Composition of customer electricity costs for grid usage

\begin{tabular}{ll}
\hline Cost component & Costs $\left[\mathrm{Ct} / \mathrm{kWh}_{\mathrm{el}}\right]$ \\
\hline Grid fees & 6.760 \\
EEG surcharge & 6.170 \\
Cogeneration levy & 0.254 \\
Offshore liability & -0.051 \\
Concession fee & 1.660 \\
§19 StromNEV levy & 0.237 \\
Levy for deferrable loads & 0.006 \\
Electricity tax & 2.050 \\
Sales (competitive pricing) & 7.120 \\
Value added tax & 4.600 \\
Total costs & 28.806 \\
\hline
\end{tabular}

fees and levies (grid fee, value added tax, concession fee, EEG surcharge, electricity tax, cogeneration levy and other levies) the competitive or sales pricing elements remained (profit margin and supplier's cost of purchasing wholesale power on the market). Given the mean spot market price at the EPEX SPOT in 2015 of $3.16 \mathrm{Ct} / \mathrm{kWh}_{\mathrm{el}}$, the remaining $3.96 \mathrm{Ct} / \mathrm{kWh}_{\mathrm{el}}$ of the sales cost component is assumed to be the utility margin. The tariff for the projected scenarios has been determined according to this: while the grid and regulatory components were kept constant in absolute numbers, the sales component was derived from the projected mean spot price and the fixed margin. A similar procedure was applied to the cost components of the gas tariff. Initial price is $6,6 \mathrm{Ct} / \mathrm{kWh}_{\mathrm{f}}$ with grid and regulatory fees and levies of $2,4 \mathrm{Ct} / \mathrm{kWh}_{\mathrm{f}}$ and a margin of $1,1 \mathrm{Ct} / \mathrm{kWh}_{\mathrm{f}}$.

As stated in "Pricing Preferences", every variable electricity tariff represents a compromise between the preferences of customers, who prefer less dynamic variable tariffs, and utilities, which, if technically feasible, prefer highly dynamic tariffs. Hence, for the model-based analysis of this research a total of six variable electricity tariffs, consisting of a fixed utility margin of $3.96 \mathrm{Ct} / \mathrm{kWh}_{\mathrm{el}}$ and a fluctuating price component, are designed, ranging from highly dynamic to very static. Thereby, the most static tariff is given with the FT. Table 5 lists and explains the three dynamic tariffs (dyn) as well as the three time-of use tariffs (TOU) that are applied in the model-based analysis. Additionally, with the exception of the FT each of the tariffs is illustrated in Fig. 5.

In three of these tariffs the fluctuating price component reflects the average electricity spot market price within the different tariff zones (dynamic pricing schemes). Consequently, the price levels during the same tariff zone on two different days are likely to differ from each other. In this context, the one hour $(1 \mathrm{~h})$ tariff scheme $1 \mathrm{~h}_{\text {dyn }}$ reflects the varying degree of hourly changes of the spot market prices 
Table 5 Characteristics of applied electricity tariffs $s_{e l}$

\begin{tabular}{|c|c|}
\hline Tariff identifier & Description \\
\hline FT & $\begin{array}{l}\text { Flat tariff with constant electricity price (yearly } \\
\text { avg. spot market prices }+ \text { margin) }\end{array}$ \\
\hline $1 \mathrm{~h}_{\mathrm{dyn}}$ & $\begin{array}{l}\text { Tariff with hourly changes in price (hourly avg. of } \\
\text { spot prices + margin) }\end{array}$ \\
\hline $4 \mathrm{TZ}_{\mathrm{dyn}}$ & $\begin{array}{l}\text { Tariff characterized by four price zones with } \\
\text { distinct price levels: morning, mid-day, evening } \\
\text { and night (zonally avg. of spot prices + margin) }\end{array}$ \\
\hline $\mathrm{NT} / \mathrm{HT}_{\mathrm{dyn}}$ & $\begin{array}{l}\text { Tariff having two price zones per day: day (6:00 } \\
-22: 00) \text { and night (22:00 - 6:00) (zonally avg. of } \\
\text { spot prices + margin) }\end{array}$ \\
\hline $1 \mathrm{~h}_{\mathrm{TOU}}$ & $\begin{array}{l}\text { Tariff with hourly seasonal (tariff zones during } \\
\text { days of the same season exhibit the same price } \\
\text { levels) changes in price (hourly seasonal avg. of } \\
\text { spot prices + margin) }\end{array}$ \\
\hline $4 \mathrm{TZ}_{\mathrm{TOU}}$ & $\begin{array}{l}\text { Tariff characterized by four seasonal price zones } \\
\text { with distinct price levels: morning, mid-day, } \\
\text { evening and night (zonally seasonal avg. of spot } \\
\text { prices + margin) }\end{array}$ \\
\hline $\mathrm{NT} / \mathrm{HT}_{\mathrm{TOU}}$ & $\begin{array}{l}\text { Tariff having two seasonal price zones per day: } \\
\text { day }(6: 00-22: 00) \text { and night }(22: 00-6: 00) \\
\text { (zonally seasonal avg. of spot prices + margin) }\end{array}$ \\
\hline
\end{tabular}

for energy, the four tariff zone identifier $4 \mathrm{TZ}_{\mathrm{dyn}}$ reflects the varying degree of four time-zones of every day (morning, midday, evening and night), and the low-tariff time (NT) and high-tariff time $(\mathrm{HT})$ identifier $\mathrm{NT} / \mathrm{HT}_{\text {dyn }}$ reflects the varying degree of two price zones every day.

In the remaining tariffs - although having the same tariff zones as their dynamic counterparts - the fluctuating price component reflects the average electricity spot market prices within the respective tariff zones over all days of the same type (weekday, Saturday, Sunday) and within the same season (winter, summer, transition season) of the evaluation year (time-of use pricing schemes, TOU). As mentioned in "Program Classification", in real life the price levels for the respective tariff zones in TOU pricing schemes as given in $1 \mathrm{~h}_{\mathrm{TOU}}, 4 \mathrm{TZ}_{\mathrm{TOU}}, \mathrm{NT} / \mathrm{HT}_{\mathrm{TOU}}$, are established on the basis of historical or forecasted spot market prices.

Special attention should be paid to the tariffs $4 \mathrm{TZ}_{\mathrm{dyn}}$ and $4 \mathrm{TZ}_{\mathrm{TOU}}$, since their tariff zones are not assigned to the same fixed times over the whole year, as it is done for the other tariffs, but orientate themselves along the average spot market price level during days of the same type/season. The two peak price tariff zones, one in the morning, the other one in the evening, lasting 4 hours each, are assigned to cover the peak price periods of electricity on the spot market. Therefore, the first tariff zone - the morning - lasts, for example, from 6:00 to 10:00 on a weekday in winter, while it lasts from 7:00 to 11:00 and from 8:00 to 12:00 on a Sunday in summer. A complete overview of the tariff zone
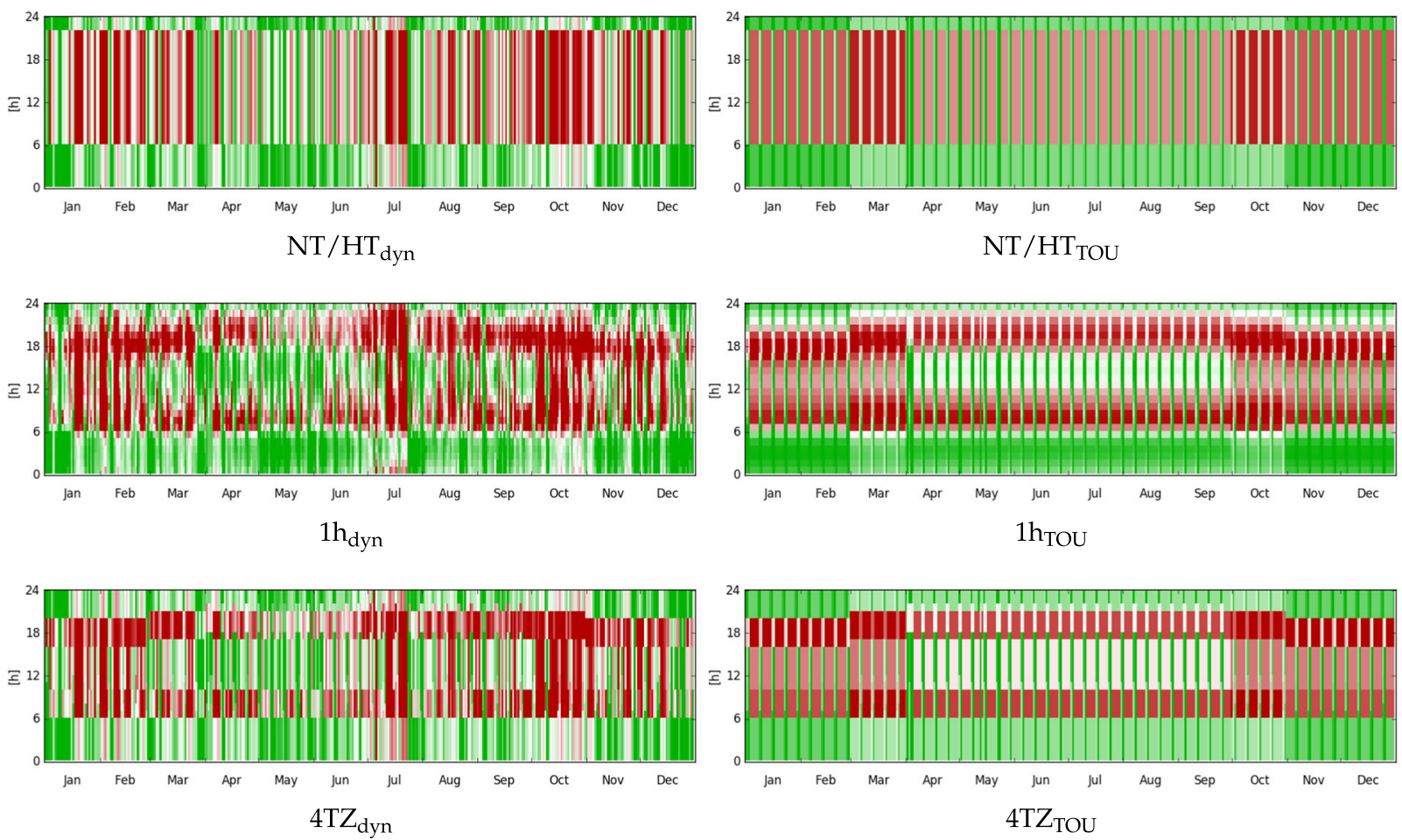

$60 € / M W h$

$72 € / M W h$

$84 € / M W h$

Fig. 5 Applied time-of-use (TOU) and dynamic (dyn) electricity tariffs of the year 2015 (competitive pricing elements only) 
assignment in tariffs $4 \mathrm{TZ}_{\mathrm{dyn}}$ and $\mathrm{TZ} 4_{\mathrm{TOu}}$ can be found in the Appendix.

In the second stage of this research (Model Confiq II), the presented set of tariffs is reduced to the three tariffs that led to the best results in Model Confiq I and is further complemented by modified versions of these three tariffs. The modification is based on the DR pattern of customers and the generation profile of the two municipal energy utilities. More concretely, the customer electricity price is decreased by $0.4 \mathrm{Ct} / \mathrm{kWh}_{\mathrm{el}}$ in time steps in which:

- the generation from utility owned facilities is $20 \%$ higher than the residential electricity demand and

- households do not show any upward demand shifts in the model run applying the unmodified original tariff.

\section{Shifting Parameters}

As stated in "Shifting Potential", without taking electric heating systems into account, the realistic maximum share of shiftable residential electricity consumption is approximately $30 \%$. Hence, in Model Confiq I, the set $\mathrm{DR}_{\mathrm{LS}}$ of applied values for the parameter share of total shiftable load includes elements ranging from 0.1 to 0.3 in steps

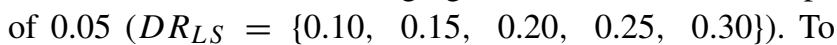
set an upper boundary for the parameter load shift horizon is a more complex task. This is due to the fact that each electric household appliance exhibits a distinct load shift horizon. Since only one single value serves as an input into the model, this value can be regarded as the average load shift horizon, taking the distinct load shift horizons of all DR capable appliances into account. Based on the information presented in "Shifting Potential", the longest load shift horizon that is applied in the scenarios of Model Confiq I is three hours. However, it has to be noted that, to reach this maximum average value, the insulation of all cooling appliances needs to be optimal and customers need to make use of the DR potential of their semi-automatically controlled appliances. The set $\mathrm{DR}_{\mathrm{SH}}$ of applied values for the parameter load shift horizon in Model Confiq I includes values from $1 \mathrm{~h}$ to $3 \mathrm{~h}$ in half hour steps $\left(D R_{S H}=\right.$ $\{1.0 \mathrm{~h}, 1.5 \mathrm{~h}, 2.0 \mathrm{~h}, 2.5 \mathrm{~h}, 3.0 \mathrm{~h}\})$. In Model Confiq II, both DR parameters are fixed at realistic specific values; share of total shiftable load is set to 0.2 , while load shift horizon is fixed at 2 hours (see "Shifting Potential").

\section{Load Profiles}

The residential customers of customer group 1 (CG1) and customer group 2 (CG2) are assigned with slightly different electrical load profiles. These are taken from a household load profile set of HTW Berlin [41] with a temporal resolution of one minute, which are adapted to the quarterhourly resolution of IRPopt. The load profiles are scaled to a yearly electricity consumption of $3500 \mathrm{kWh}_{\mathrm{el}}$. The heating load profiles for customers of customer group 2 are derived on the basis of the Hellwig methodology [22]. It is assumed that these customers live in new single-family houses with an average heating demand of $13600 \mathrm{kWh}_{\text {th }}$ (th for thermal energy) per year.

\section{Technology Characteristics}

Tables $6,7,8$ and 9 give a comprehensive overview of characteristics of customer side and utility side technologies that are applied in the model. In all scenarios in Model Confiq II, customers from CG2 are equipped with the identical heat pump system. In contrast, the size and, consequently, the investment cost of the applied thermal buffer storage depends on the selected tariff scheme. In the reference case, in which a FT is applied a thermal buffer storage of $250 \mathrm{l}$, corresponding to a maximum thermal capacity of approximately $15 \mathrm{kWh}_{\text {th }}$, is used. In all other scenarios, characterized by time-variable tariffs, the applied thermal buffer storage has a size of 5001 , or a thermal capacity of approximately $30 \mathrm{kWh}_{\mathrm{th}}$. The values pertaining to the scenarios with time-variable tariffs are listed in brackets in Table 7.

The applied heat pump is a ground-source heat pump with a constant coefficient of power (COP) of 4. Since this work does not aim at a cost comparison of different heating systems, the investment costs and the technical life time of the heat pump are of no importance. An important characteristic regarding demand shifts is the self-discharge rate, which is assumed to be $0.1 \%$ per time step. The technical lifetime of both technologies is assumed to be 20 years.

On the utility side, the wind energy plant is scaled via the rotor diameter in such a way that its electricity generation exceeds the demand of the residential customers for a considerable amount of time intervals. In these times, the municipal energy utility has the opportunity to gain additional profit by adapting their electricity tariff to foster demand shifts. Assuming a FT, the designed wind energy plant covers approximately $60 \%$ of the residential demand in 2015. The wind speed data used as input into the model runs is taken from the meteonorm databank [27] and

Table 6 Heat pump characteristics

\begin{tabular}{lll}
\hline Characteristic & Value & Unit \\
\hline Maximum thermal power & 9 & $\mathrm{~kW}_{\text {th }}$ \\
COP & 4 & \\
\hline
\end{tabular}


Table 7 Thermal storage characteristics

\begin{tabular}{lll}
\hline Characteristic & Value & Unit \\
\hline Maximum thermal capacity & $15(30)$ & $\mathrm{kWh}_{\mathrm{th}}$ \\
Maximum state of charge & 100 & $\%$ \\
Minimum state of charge & 0 & $\%$ \\
Maximum charging capacity & 21 & $\mathrm{~kW}_{\mathrm{th}}$ \\
Maximum discharge capacity & 21 & $\mathrm{~kW}_{\text {th }}$ \\
Self-discharge rate & 0.10 & $\% / 15$ min \\
Technical lifetime & 20 & years \\
Investment costs & $1050(1200)$ & $€$ \\
\hline
\end{tabular}

corresponds to data that was recorded in Kiel/Holtenau in the year 2005 .

In the design of the combined heat and power (CHP) plant, attention is paid to the fact that the heating demand of the customers connected to the district heating grid can be satisfied at any point. The values of the generation facilities were chosen on the basis of a survey of available information.

\section{Case Overview}

To explore challenges and opportunities of residential DR, this research deploys a scenario based analysis at neighborhood scale, considering different market actors, system processes as well as system relations. Table 10 lists the optimization cases of this research paper with respect to the utility and customer characteristics. The research consists of two stages: Model Confiq I (MTI) and Model Confiq II (MTII).

Three types of utilities are distinguished: low-priced orchestrator (LO), green municipal utility (GMU) and conventional municipal utility (CMU). Cases in research stages MTI and MTII are characterized by different customer

Table 8 Wind energy plant characteristics

\begin{tabular}{lll}
\hline Characteristic & Value & Unit \\
\hline Maximum capacity & 0.76 & $\mathrm{MW}$ \\
Power coefficient $\mathrm{C}_{\mathrm{p}}$ & 0.50 & \\
Generator efficiency & 98 & $\%$ \\
Drive train efficiency & 98 & $\mathrm{~m}$ \\
Rotor diameter & 31.62 & $\mathrm{~m}$ \\
Hub height & 130 & $\mathrm{~kg} / \mathrm{m}^{3}$ \\
Air density at hub height & 1.20 & $\mathrm{~m} / \mathrm{s}$ \\
Nominal wind speed & 15 & $\mathrm{~m} / \mathrm{s}$ \\
Start-up speed & 3 & $\mathrm{~m} / \mathrm{s}$ \\
Shut-down speed & 25 & years \\
Technical lifetime & 20 & \\
\hline
\end{tabular}

Table 9 CHP plant characteristics

\begin{tabular}{lll}
\hline Characteristic & Value & Unit \\
\hline Maximum electric capacity & 0.30 & MW \\
Minimum electric capacity & 0 & MW \\
Electric efficiency & 0.27 & \\
Power to heat ratio & 0.50 & \\
Technical lifetime & 20 & years \\
\hline
\end{tabular}

structures. While in scenarios with MTI, only customers from CG1 are included, scenarios with MTII also take customers from CG2 into account. In this context, each customer group also consists of different individual households equipped with respective loads and decentralized technologies. In this context, the municipality posses a high share of renewables on the basis of a wind turbine of the GMU. Furthermore, while CG1 serves their heating load with gas boilers, CG2 takes heat pumps into account.

Additionally, in MTI, one FT as well as six variable tariffs $\left(1 \mathrm{~h}_{\text {dyn }}, 4 \mathrm{TZ}_{\mathrm{dyn}}, \mathrm{NT} / \mathrm{HT}_{\mathrm{dyn}}, 1 \mathrm{~h}_{\mathrm{TOU}}, 4 \mathrm{TZ}_{\mathrm{TOU}}\right.$, $\mathrm{NT} / \mathrm{HT}_{\mathrm{TOU}}$ ) serve as input for the different business cases. In contrast, for cases in MTII, only the three tariffs that perform best in MTI are selected. In Table 10, these tariffs are listed as T1, T2 and T3.

Additional tariffs $\left(\mathrm{T} 1_{\text {mod,GMU }}, \mathrm{T} 2_{\text {mod,GMU }}, \mathrm{T} 3_{\text {mod,GMU }}\right.$ and $\mathrm{T} 1_{\text {mod,CMU }}, \mathrm{T} 2_{\text {mod,CMU }}, \mathrm{T} 3_{\text {mod,CMU }}$ ) are created by modifying these tariffs based on the DR pattern that customers exhibit when being exposed to the original tariffs and the generation profile of the utilities, the GMU and the CMU. The optimization scenarios in which a FT is applied and no DR is performed by the customers, represents the reference case. Next to the economic assessment, this part of the research also investigates the effects of residential DR on the energy autonomy of municipalities, or, in other words, their independence from external electricity production. In this work, the level of energy autonomy is defined as the quotient of the consumption of locally produced electricity and the total electricity consumption of residential customers.

In addition, in MTI, the decisive DR parameters - share of total shiftable load $D R_{L S}$ and load shift horizon $D R_{S H}$ - demonstrate sensitivity parameters and thus are varied between the individual optimization cases to assess the influence of both parameters on customer savings and utility earnings. Detailed information about the shifting parameters is also given in the next subsection.

Moreover, as described before, while the evaluation in MTI concentrates solely on the year 2015, the evaluation period in MTII is broadened to 2015, 2025 and 2035. This allows an assessment of the overall potential. 
Table 10 Optimization scenarios

\begin{tabular}{|c|c|c|c|c|}
\hline \multirow[t]{2}{*}{ Research stage } & \multicolumn{4}{|c|}{ Utility and customer characteristics } \\
\hline & Utility type & Tariff scheme & DR parameters & CG setting \\
\hline MT I & LO & FT & - & CG1 \\
\hline MT I & LO & $1 \mathrm{~h}_{\text {dyn }}$ & {$\left[D R_{L S}\right] \times\left[D R_{S H}\right]$} & CG1 \\
\hline MT I & LO & $4 \mathrm{TZ}_{\mathrm{dyn}}$ & {$\left[D R_{L S}\right] \times\left[D R_{S H}\right]$} & CG1 \\
\hline MT I & LO & $\mathrm{NT} / \mathrm{HT}_{\text {dyn }}$ & {$\left[D R_{L S}\right] \times\left[D R_{S H}\right]$} & CG1 \\
\hline MT I & LO & $1 \mathrm{~h}_{\mathrm{TOU}}$ & {$\left[D R_{L S}\right] \times\left[D R_{S H}\right]$} & CG1 \\
\hline MT I & LO & $4 \mathrm{TZ}_{\mathrm{TOU}}$ & {$\left[D R_{L S}\right] \times\left[D R_{S H}\right]$} & CG1 \\
\hline MT I & LO & $\mathrm{NT} / \mathrm{HT}_{\mathrm{TOU}}$ & {$\left[D R_{L S}\right] \times\left[D R_{S H}\right]$} & CG1 \\
\hline MT II & LO & FT & - & $\mathrm{CG} 1 / 2$ \\
\hline MT II & LO & $\mathrm{T} 1$ & $0.2,2.0 \mathrm{~h}$ & $\mathrm{CG} 1 / 2$ \\
\hline MT II & LO & $\mathrm{T} 2$ & $0.2,2.0 \mathrm{~h}$ & $\mathrm{CG} 1 / 2$ \\
\hline MT II & LO & $\mathrm{T} 3$ & $0.2,2.0 \mathrm{~h}$ & $\mathrm{CG} 1 / 2$ \\
\hline MT II & GMU & FT & $0.2,2.0 \mathrm{~h}$ & $\mathrm{CG} 1 / 2$ \\
\hline MT II & GMU & $\mathrm{T} 1$ & $0.2,2.0 \mathrm{~h}$ & $\mathrm{CG} 1 / 2$ \\
\hline MT II & GMU & $\mathrm{T} 2$ & $0.2,2.0 \mathrm{~h}$ & $\mathrm{CG} 1 / 2$ \\
\hline MT II & GMU & $\mathrm{T} 3$ & $0.2,2.0 \mathrm{~h}$ & $\mathrm{CG} 1 / 2$ \\
\hline MT II & GMU & $\mathrm{T} 1_{\text {mod,GMU }}$ & $0.2,2.0 \mathrm{~h}$ & CG1/2 \\
\hline MT II & GMU & $\mathrm{T} 22_{\text {mod,GMU }}$ & $0.2,2.0 \mathrm{~h}$ & $\mathrm{CG} 1 / 2$ \\
\hline MT II & GMU & $\mathrm{T} 3_{\text {mod,GMU }}$ & $0.2,2.0 \mathrm{~h}$ & $\mathrm{CG} 1 / 2$ \\
\hline MT II & $\mathrm{CMU}$ & FT & - & $\mathrm{CG} 1 / 2$ \\
\hline MT II & $\mathrm{CMU}$ & $\mathrm{T} 1$ & $0.2,2.0 \mathrm{~h}$ & $\mathrm{CG} 1 / 2$ \\
\hline MT II & $\mathrm{CMU}$ & $\mathrm{T} 2$ & $0.2,2.0 \mathrm{~h}$ & $\mathrm{CG} 1 / 2$ \\
\hline MT II & CMU & T3 & $0.2,2.0 \mathrm{~h}$ & CG1/2 \\
\hline MT II & $\mathrm{CMU}$ & $\mathrm{T} 1_{\text {mod,CMU }}$ & $0.2,2.0 \mathrm{~h}$ & $\mathrm{CG} 1 / 2$ \\
\hline MT II & $\mathrm{CMU}$ & $\mathrm{T} 2{ }_{\text {mod,CMU }}$ & $0.2,2.0 \mathrm{~h}$ & $\mathrm{CG} 1 / 2$ \\
\hline MT II & CMU & $\mathrm{T} 3_{\text {mod,CMU }}$ & $0.2,2.0 \mathrm{~h}$ & $\mathrm{CG} 1 / 2$ \\
\hline
\end{tabular}

\section{Optimization Results}

\section{Model Confiq I}

Figure 6 depicts the change in customer, utility and combined results per household when applying tariff $1 h_{\text {dyn }}$ compared to the results of the reference model run for varying values of load shift horizon $(1.5 \mathrm{~h}-3.0 \mathrm{~h})$ and share of total shiftable load $(10-30 \%)$ in the year 2015. The results show that even when residential customers who exclusively perform DR with the help of electric household appliances are exposed to a very dynamic variable electricity tariff, such as $1 \mathrm{~h}_{\mathrm{dyn}}$, they are financially worse off than in the reference case, in which they are facing a FT with no opportunity to perform DR. The shorter the load shift horizon and the smaller the share of total shiftable load, the worse the customer results are. By contrast, the results of the utility, a LO in this stage of the research, are higher than in the reference case in every instance in which customers are able to perform DR. Furthermore, it can be observed that a change in the DR parameters has only a minimal effect on the utility result, which decreases slightly with an increase of the share of total shiftable load and stays approximately constant over varying load shift horizons. The combined results, the sum of customer and utility results, is calculated to see if any gains in overall welfare can be achieved by residential DR provoked through a specific variable electricity tariff. For tariff $1 \mathrm{~h}_{\mathrm{dyn}}$, the combined results are positive for all model runs with a load shift horizon equal to or longer than $1.5 \mathrm{~h}$ and a share of total shiftable load equal or larger than $15 \%$.

Figure 7 shows the change in customer, utility and combined results per household for all six variable electricity tariffs and the specific DR parameter combination of $2.0 \mathrm{~h}$ and $20 \%$. While both $\mathrm{NT} / \mathrm{HT}_{\mathrm{dyn}}$ and $\mathrm{NT} / \mathrm{HT}_{\mathrm{TOU}}$ show poor results, the greatest overall welfare gains are achieved by tariff $1 h_{\text {dyn }}$, followed by tariffs $1 h_{T O U}$, $4 \mathrm{TZ}_{\mathrm{dyn}}$ and $4 \mathrm{TZ}_{\mathrm{TOU}}$, all three of which show similar results. Although tariff $1 \mathrm{~h}_{\text {TOU }}$ performs slightly better than the other two tariffs at the fixed DR parameter combination, tariffs $4 \mathrm{TZ}_{\mathrm{dyn}}$ and $4 \mathrm{TZ}_{\mathrm{TOU}}$ are selected for the further analysis in stage Model Confiq II, along with tariff $1 \mathrm{~h}_{\mathrm{dyn}}$. This is justified by the fact that customers prefer variable tariffs with 


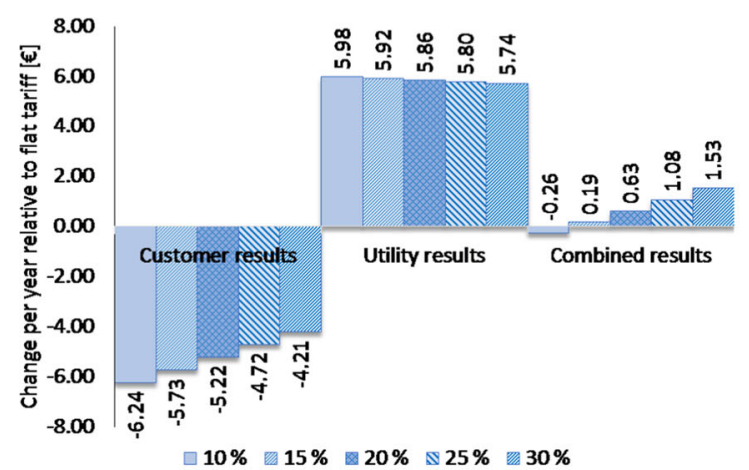

Load shift horizon: $1.5 \mathrm{~h}$

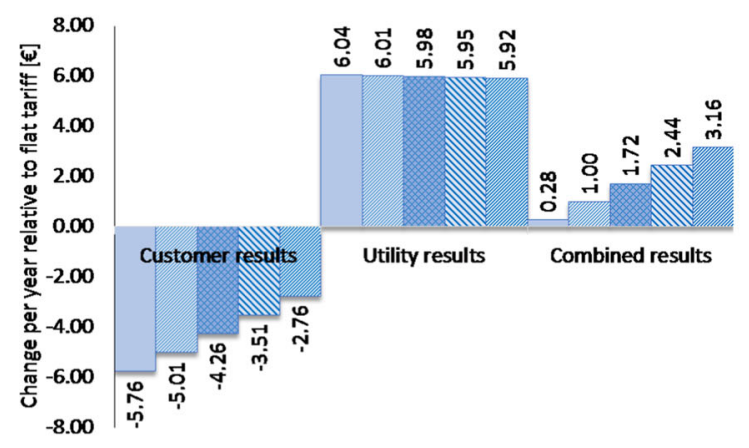

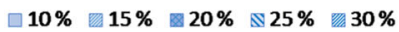

Load shift horizon: $2.5 \mathrm{~h}$

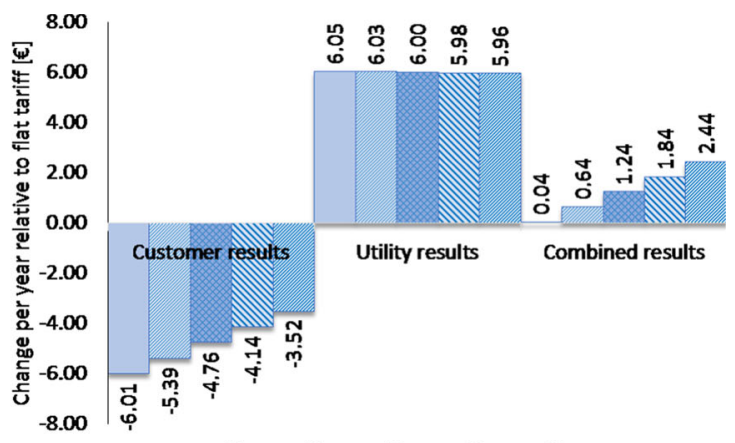

$\square 10 \% \square 15 \% \square 20 \% ₫ 25 \% \square 30 \%$

Load shift horizon: $2.0 \mathrm{~h}$

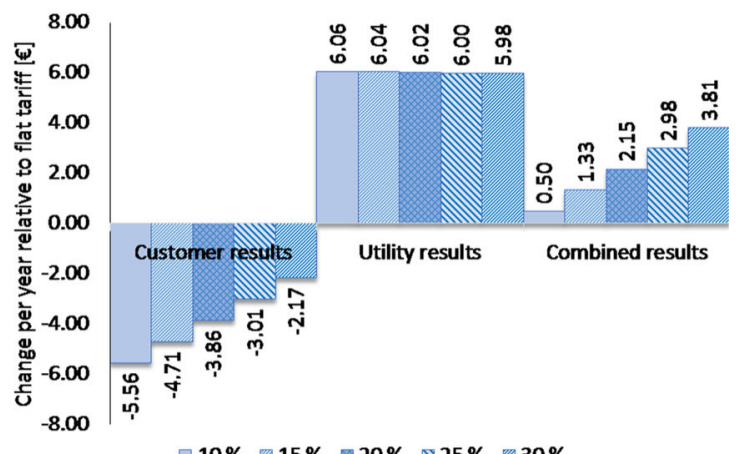

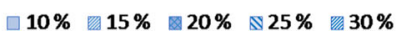

Load shift horizon: $3.0 \mathrm{~h}$

Fig. 6 Change in customer, utility and combined results in 2015 when applying tariff $1 \mathrm{~h}_{\text {dyn }}$ compared to a FT for varying load shift horizons and shares of total shiftable load of $10-30 \%$
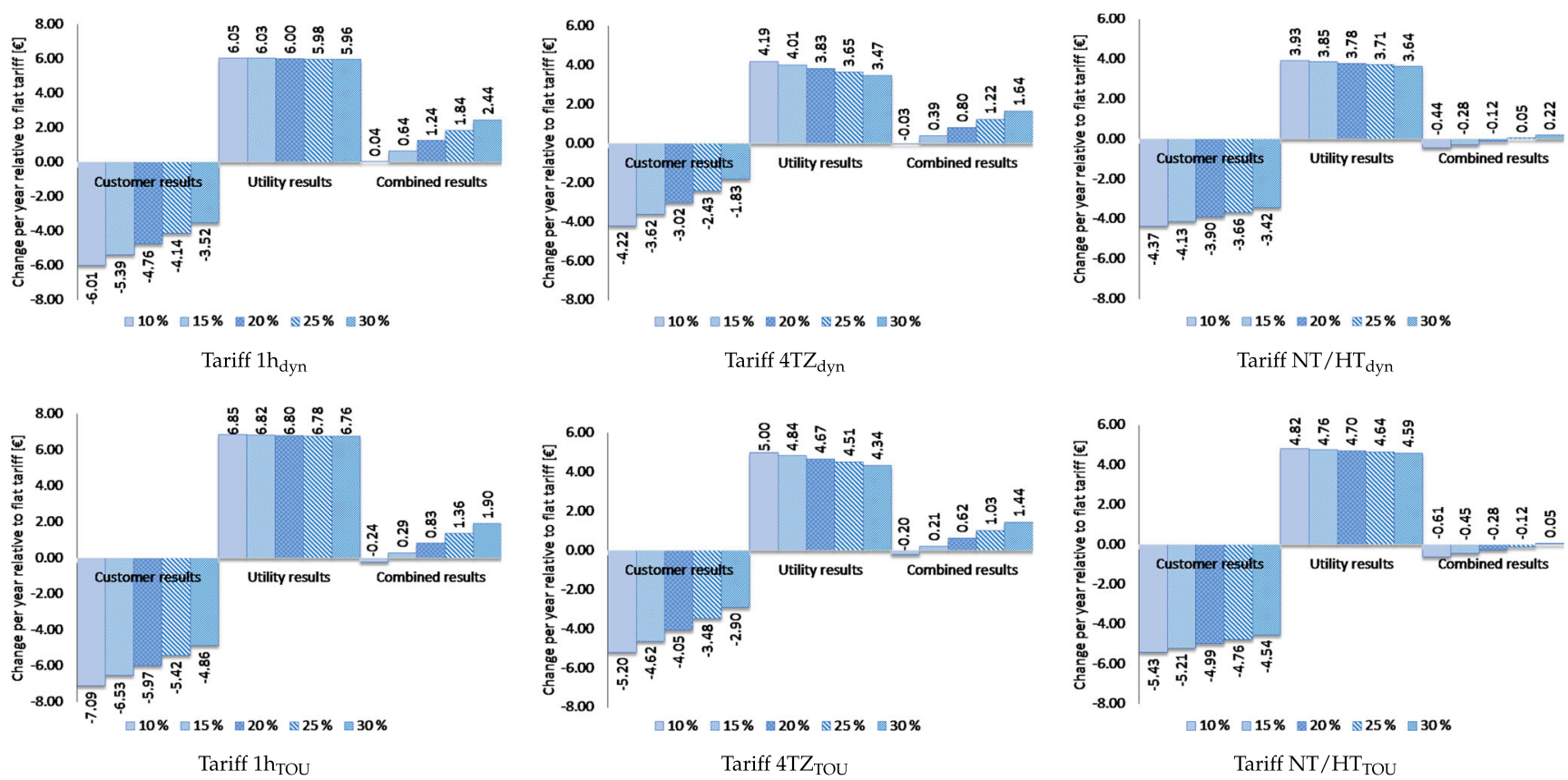

Fig. 7 Change in customer, utility and combined results in 2015 when applying a variable tariff compared to a FT for a fixed load shift horizon of $2 \mathrm{~h}$ and shares of total shiftable load of $10-30 \%$ 
fewer price levels over alternative options with more price levels.

Figure 8 gives a complete overview of the change in combined results per customer relative to the base case results for all applied variable electricity tariffs over all possible DR parameter combinations. While tariffs $\mathrm{NT} / \mathrm{HT}_{\mathrm{dyn}}$ and $\mathrm{NT} / \mathrm{HT}_{\mathrm{TOU}}$ show hardly any economic potential, the other tariffs have a small economic potential, which is in this stage still exclusively performed by electric household appliances. Naturally, the larger the share of total shiftable load and the longer the load shift horizon, the bigger the economic potential of variable electricity tariffs. Nevertheless, in order to achieve any gains in overall welfare, even in the scenarios with the four best performing tariffs $\left(1 \mathrm{~h}_{\mathrm{TOU}}, 1 \mathrm{~h}_{\mathrm{TOU}}, 4 \mathrm{TZ}_{\mathrm{dyn}}\right.$ and $\left.4 \mathrm{TZ}_{\mathrm{TOU}}\right)$, households need to reach a share of total shiftable load of at least $20 \%$ and a load shift horizon of two hours.

\section{Model Confiq II}

Tables 11, 12 and 13 list the economic results of the optimization scenarios of stage Model Confiq II. Each table

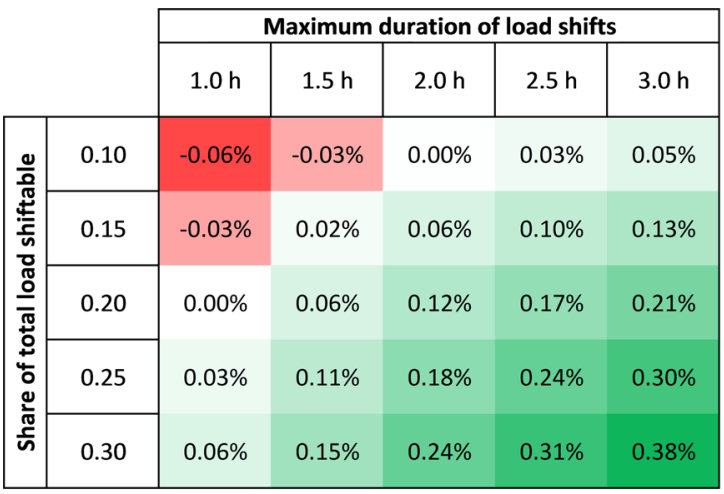

Tariff $1 h_{\text {dyn }}$

\begin{tabular}{|c|c|c|c|c|c|c|}
\hline & \multicolumn{5}{|c|}{ Maximum duration of load shifts } \\
\hline & & $1.0 \mathrm{~h}$ & $1.5 \mathrm{~h}$ & $2.0 \mathrm{~h}$ & $2.5 \mathrm{~h}$ & $3.0 \mathrm{~h}$ \\
\hline \multirow{5}{*}{ 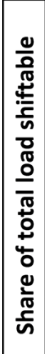 } & 0.10 & $-0.06 \%$ & $-0.03 \%$ & $0.00 \%$ & $0.02 \%$ & $0.04 \%$ \\
\hline & 0.15 & $-0.04 \%$ & $-0.01 \%$ & $0.04 \%$ & $0.07 \%$ & $0.10 \%$ \\
\hline & 0.20 & $-0.03 \%$ & $0.02 \%$ & $0.08 \%$ & $0.13 \%$ & $0.17 \%$ \\
\hline & 0.25 & $-0.01 \%$ & $0.05 \%$ & $0.12 \%$ & $0.18 \%$ & $0.23 \%$ \\
\hline & 0.30 & $0.00 \%$ & $0.07 \%$ & $0.16 \%$ & $0.23 \%$ & $0.30 \%$ \\
\hline
\end{tabular}

Tariff $4 \mathrm{TZ}_{\mathrm{dyn}}$

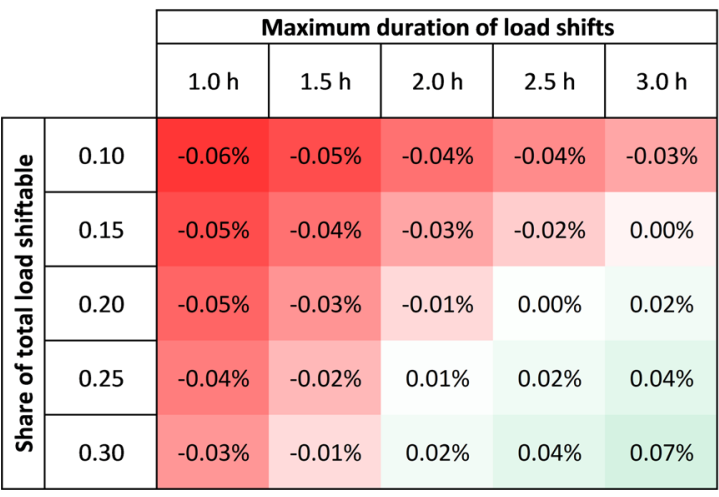

Tariff NT/ $\mathrm{HT}_{\text {dyn }}$

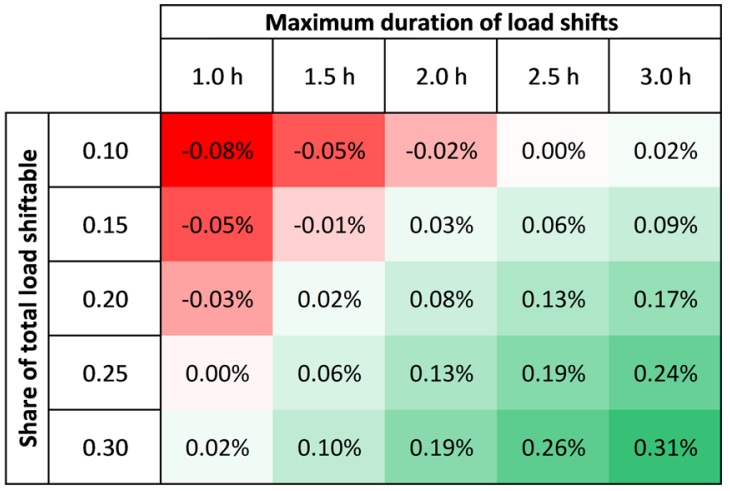

Tariff $1 \mathrm{~h}_{\mathrm{TOU}}$

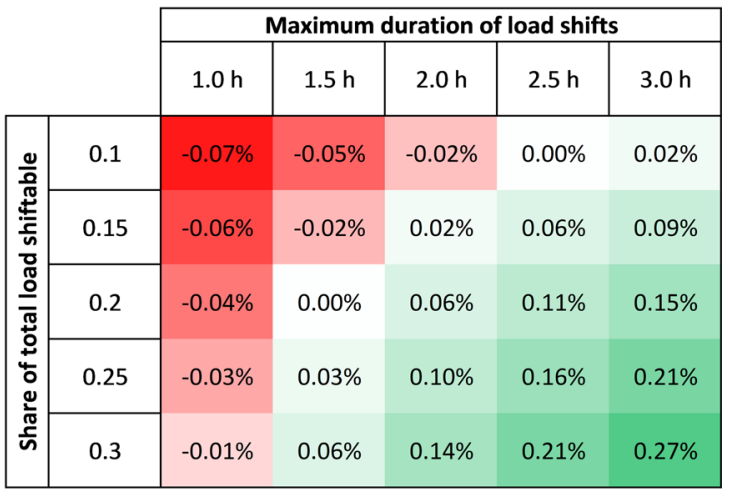

Tariff $4 \mathrm{TZ}_{\mathrm{TOU}}$

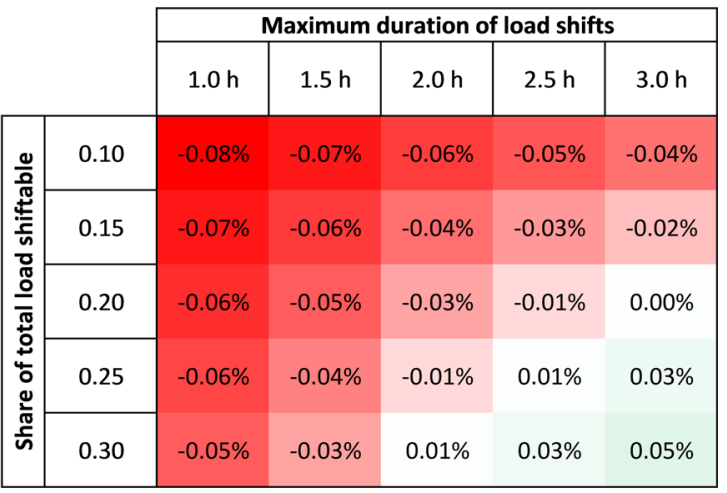

Tariff NT/ $\mathrm{HT}_{\mathrm{TOU}}$

Fig. 8 Change in combined results per customer relative to base case results for all variable tariffs over all possible DR parameter combinations displayed as share of base case customer electricity costs 
Table 11 Change in customer, utility (LO) and combined results per household in 2015, 2025 and 2035 when applying variable tariffs compared to a FT (in €)

\begin{tabular}{|c|c|c|c|c|c|c|c|}
\hline Tariff & Year & CG1 & Utility $_{C G 1}$ & $\begin{array}{l}\text { Combined } \\
\text { CG1/Utility }{ }_{C G 1}\end{array}$ & $\mathrm{CG} 2_{\mathrm{HP}}$ & Utility $_{\mathrm{CG} 2 \mathrm{HP}}$ & $\begin{array}{l}\text { Combined } \\
\mathrm{CG} 2_{\mathrm{HP}} / \text { Utility }_{\mathrm{CG}} 2_{\mathrm{HP}}\end{array}$ \\
\hline \multirow[t]{3}{*}{$1 h_{d y n}$} & 2015 & -4.76 & 6.00 & 1.24 & 1.14 & 12.25 & 13.40 \\
\hline & 2025 & -3.64 & 4.78 & 1.14 & 0.33 & 13.88 & 14.21 \\
\hline & 2035 & -3.86 & 6.42 & 2.56 & 12.03 & 29.90 & 41.93 \\
\hline \multirow[t]{3}{*}{$4 \mathrm{TZ}_{\mathrm{dyn}}$} & 2015 & -3.02 & 3.83 & 0.81 & -3.27 & 9.37 & 6.10 \\
\hline & 2025 & -1.52 & 2.12 & 0.60 & -6.71 & 9.53 & 2.82 \\
\hline & 2035 & -1.40 & 2.93 & 1.53 & 0.16 & 22.05 & 22.21 \\
\hline \multirow[t]{3}{*}{$4 \mathrm{TZ}_{\mathrm{TOU}}$} & 2015 & -4.05 & 4.67 & 0.62 & -8.29 & 11.20 & 2.91 \\
\hline & 2025 & -2.11 & 2.56 & 0.45 & -12.94 & 7.58 & -5.36 \\
\hline & 2035 & -3.51 & 4.62 & 1.11 & -14.67 & 21.38 & 6.71 \\
\hline
\end{tabular}

depicts the change in customer groups ( $C G 1 / C G 2)$, utility earnings of each of the customer groups (Utility CG1 $_{\text {I }}$ / Utility $_{\mathrm{CG} 2}$ ) and combined results with respect to the base case results for one of the three different types of energy utilities that are included in the analysis. Customer and utility results that can be attributed to customers from CG1, who solely perform DR with electric household appliances, are listed separately from the results that are attributable explicitly to the use of a heating system combining an electric heat pump (HP) with a thermal buffer storage system of customers from CG2 (in order to analyze costs for heat pump separately, the $\mathrm{CG} 2$ is depicted with $\mathrm{CG} 2_{\mathrm{HP}}$ ). As depicted before, all optimization scenarios of this research stage have been optimized on the data basis of 2015, 2025 and 2035.
First of all, the optimized scenarios support the outcomes from Model Confiq I. The tariffs $\mathrm{h}_{\mathrm{dyn}}, 4 \mathrm{TZ}_{\mathrm{dyn}}$ and $4 \mathrm{TZ}_{\mathrm{TOU}}$ show a small economic potential in the context of DR performed by customers from CG1 for the LO in the years 2025 and 2035. A very similar picture presents itself when looking at the respective results for the CMU and the GMU. The only exceptions are the optimization scenarios for tariff $4 \mathrm{TZ}_{\mathrm{TOU}}$ in the year 2025 , in which the combined results are negative.

Additionally, it can be observed that variable electricity tariffs exhibit a considerable economic potential in the context of DR performed by heating systems combining an electric heat pump with a thermal buffer storage system. Independent of the type of utility, tariff $1 \mathrm{~h}_{\mathrm{dyn}}$ shows much better combined results than tariff $4 \mathrm{TZ}_{\mathrm{dyn}}$, which in turn,
Table 12 Change in customer, utility (GMU) and combined results per household in 2015, 2025 and 2035 when applying variable tariffs compared to a FT (in €)

\begin{tabular}{|c|c|c|c|c|c|c|c|}
\hline Tariff & Year & CG1 & Utility $_{\text {CG1 }}$ & $\begin{array}{l}\text { Combined } \\
\text { CG1/UtilityCG1 }\end{array}$ & $\mathrm{CG} 2_{\mathrm{HP}}$ & Utility $_{\mathrm{CG}} \mathrm{HP}_{\mathrm{HP}}$ & $\begin{array}{l}\text { Combined } \\
\mathrm{CG} 2_{\mathrm{HP}} / \mathrm{Utility} \mathrm{CG}_{\mathrm{HP}}\end{array}$ \\
\hline \multirow[t]{3}{*}{$1 h_{\text {dyn }}$} & 2015 & -4.76 & 5.99 & 1.23 & 5.90 & 6.17 & 12.07 \\
\hline & 2025 & -3.54 & 1.85 & -1.69 & 2.64 & 13.02 & 15.66 \\
\hline & 2035 & -3.86 & 6.39 & 2.53 & 15.89 & 23.48 & 39.37 \\
\hline \multirow[t]{3}{*}{$1 \mathrm{~h}_{\mathrm{dyn}, \mathrm{mod}, \mathrm{GMU}}$} & 2015 & -2.92 & 4.30 & 1.38 & 7.86 & 3.87 & 11.73 \\
\hline & 2025 & -1.55 & 0.07 & -1.48 & 5.07 & 10.17 & 15.24 \\
\hline & 2035 & -2.08 & 4.85 & 2.77 & 17.73 & 22.65 & 39.38 \\
\hline \multirow[t]{3}{*}{$4 \mathrm{TZ}_{\mathrm{dyn}}$} & 2015 & -3.03 & 3.76 & 0.73 & -0.24 & 5.60 & 5.36 \\
\hline & 2025 & -1.41 & -0.86 & -2.27 & -6.59 & 11.47 & 4.88 \\
\hline & 2035 & -1.40 & 2.85 & 1.45 & 1.56 & 19.21 & 20.77 \\
\hline \multirow[t]{3}{*}{$4 \mathrm{TZ}_{\mathrm{dyn}, \mathrm{mod}, \mathrm{GMU}}$} & 2015 & -0.94 & 2.02 & 1.08 & 2.37 & 2.94 & 5.31 \\
\hline & 2025 & 0.69 & -2.63 & -1.94 & -3.39 & 8.70 & 5.30 \\
\hline & 2035 & 0.59 & 1.19 & 1.78 & 3.95 & 18.01 & 21.96 \\
\hline \multirow[t]{3}{*}{$4 \mathrm{TZ}_{\mathrm{TOU}}$} & 2015 & -4.05 & 4.61 & 0.59 & -4.24 & 6.66 & 2.42 \\
\hline & 2025 & -2.02 & -0.41 & -2.43 & -12.03 & 9.03 & -3.00 \\
\hline & 2035 & -3.51 & 4.54 & 1.03 & -11.21 & 16.93 & 5.72 \\
\hline \multirow[t]{3}{*}{$4 \mathrm{TZ}_{\mathrm{TOU}, \mathrm{mod}, \mathrm{GMU}}$} & 2015 & -2.00 & 2.91 & 0.91 & -1.77 & 3.81 & 2.03 \\
\hline & 2025 & 0.05 & -2.12 & -2.07 & -9.12 & 5.90 & -3.22 \\
\hline & 2035 & -1.46 & 2.83 & 1.37 & -8.92 & 15.65 & 6.73 \\
\hline
\end{tabular}


Table 13 Change in customer, utility (CMU) and combined results per household in 2015, 2025 and 2035 when applying variable tariffs compared to a FT (in $€)$

\begin{tabular}{|c|c|c|c|c|c|c|c|}
\hline Tariff & Year & CG1 & Utility $_{C G 1}$ & $\begin{array}{l}\text { Combined } \\
\text { CG1/Utility }{ }_{C G 1}\end{array}$ & $\mathrm{CG} 2_{\mathrm{HP}}$ & Utility $_{\mathrm{CG} 2} \mathrm{HP}_{\mathrm{P}}$ & $\begin{array}{l}\text { Combined } \\
\mathrm{CG} 2_{\mathrm{HP}} / \text { Utility }_{\mathrm{CG} 2 \mathrm{HP}}\end{array}$ \\
\hline \multirow[t]{3}{*}{$1 h_{d y n}$} & 2015 & -4.76 & 5.99 & 1.23 & 5.90 & 6.18 & 12.08 \\
\hline & 2025 & -3.55 & 4.69 & 1.14 & 2.65 & 10.18 & 12.83 \\
\hline & 2035 & -3.86 & 6.39 & 2.53 & 15.89 & 23.48 & 39.37 \\
\hline \multirow[t]{3}{*}{$1 \mathrm{~h}_{\mathrm{dyn}, \mathrm{mod}, \mathrm{GMU}}$} & 2015 & -2.24 & 2.65 & 0.41 & 8.94 & 3.83 & 12.77 \\
\hline & 2025 & -0.92 & 2.33 & 1.41 & 6.65 & 5.55 & 12.20 \\
\hline & 2035 & -1.62 & 4.45 & 2.83 & 19.00 & 20.35 & 39.35 \\
\hline \multirow[t]{3}{*}{$4 \mathrm{TZ}_{\mathrm{dyn}}$} & 2015 & -3.03 & 3.76 & 0.73 & -0.24 & 5.61 & 5.37 \\
\hline & 2025 & -1.42 & 1.98 & 0.56 & -6.58 & 8.66 & 2.08 \\
\hline & 2035 & -1.40 & 2.85 & 1.45 & 1.56 & 19.21 & 20.77 \\
\hline \multirow[t]{3}{*}{$4 \mathrm{TZ}_{\mathrm{dyn}, \mathrm{mod}, \mathrm{GMU}}$} & 2015 & -0.16 & 1.40 & 1.24 & 3.90 & 1.18 & 5.08 \\
\hline & 2025 & 1.46 & -0.43 & 1.03 & -1.25 & 3.60 & 2.35 \\
\hline & 2035 & 1.16 & 0.76 & 1.92 & 5.52 & 16.08 & 21.60 \\
\hline \multirow[t]{3}{*}{$4 \mathrm{TZ}_{\mathrm{TOU}}$} & 2015 & -1.20 & 2.25 & 1.05 & -0.37 & 2.30 & 1.93 \\
\hline & 2025 & -2.03 & 2.43 & 0.40 & -12.02 & 6.21 & -5.81 \\
\hline & 2035 & -3.51 & 4.53 & 1.02 & -11.16 & 16.96 & 5.81 \\
\hline \multirow[t]{3}{*}{$4 \mathrm{TZ}_{\mathrm{TOU}, \mathrm{mod}, \mathrm{GMU}}$} & 2015 & -2.00 & 2.91 & 0.91 & -1.77 & 3.81 & 2.03 \\
\hline & 2025 & 0.75 & 0.12 & 0.87 & -7.25 & 0.28 & -6.97 \\
\hline & 2035 & -0.82 & 2.33 & 1.55 & -7.58 & 13.56 & 5.98 \\
\hline
\end{tabular}

performs better than tariff $4 \mathrm{TZ}_{\mathrm{TOU}}$ in this context. It is worth mentioning that tariff $1 \mathrm{~h}_{\mathrm{dyn}}$ is the only one out of the three mentioned tariffs that leads to positive customer results throughout all evaluation years, regardless of the utility. Furthermore, the different tariff schemes lead to similar combined results for the different utility set-ups.

In most cases, the modified (mod) tariffs $1 h_{\text {dyn,mod,GMU, }}$ $4 \mathrm{TZ}_{\mathrm{dyn}, \mathrm{mod}, \mathrm{GMU}}, \quad 4 \mathrm{TZ} \mathrm{TOU}_{\mathrm{TO} \text {,mod;GU }}$ and $1 \mathrm{~h}_{\mathrm{dyn}, \mathrm{mod}, \mathrm{CMU}}$, $4 \mathrm{TZ}_{\mathrm{dyn}, \mathrm{mod}, \mathrm{CMU}}, 4 \mathrm{TZ} \mathrm{TOU}_{\mathrm{T}, \bmod , \mathrm{CMU}}$ perform equally well or even slightly better than their unmodified counterparts. In addition, Table 14 reveals a further advantage over the unmodified tariffs: they help to increase the level of energy autonomy of municipalities. While in case of the municipality with the GMU the level of energy autonomy is increased by $0.44-0.52 \%$, it is increased by $0.3-0.34 \%$ in the case of the municipality with the CMU.

\section{Business Implications}

The optimization results illustrate that variable electricity tariffs allow to exploit the economic potential lying in residential DR. However, all variable tariffs applied in this analysis put customers that perform DR with electric household appliances in a worse financial position rather than the initial FT scheme. The reason for this lies in the price risk that has to be taken on by the customers in variable pricing schemes as already stated by $[13,14]$. Consequently, to make variable electricity tariffs competitive, utilities need to transfer a portion of the gains that they realize due to residential DR to their customers.

A higher economic potential lies in DR performed by customers that run an electric heating system combining an electric heat pump. Both the high amount of electricity and the long effective load shift horizon due to the thermal buffer storage have a positive effect on the results, so that considerable gains can be achieved especially when applying highly dynamic tariffs.

Additionally, electricity tariffs that only take price differences of the spot market into account have a negative impact on the energy autonomy level of municipalities whose electricity generation relies largely on cogeneration in CHP plants. This is due to the fact that the operation of the CHP plants in the model runs is heat- and not powercontrolled. The negative impact on the energy autonomy level of municipalities with a large share of electricity production from wind energy plants is less pronounced. Basing variable electricity tariffs not solely on spot market prices, but also on the DR pattern of customers and on the specific generation profiles of municipal energy utilities helps to increase the level of energy autonomy of municipalities.

All in all, municipal energy utilities with their close customer relation and interrelation with the municipality should be especially able to exploit the small, but existing potential if the following aspects are taken into consideration in the design of suitable business models:

- variable tariffs should be designed by taking into account the price structure of the spot market with 
Table 14 Change in the level of energy autonomy of the investigated municipality

\begin{tabular}{|c|c|c|c|}
\hline Utility & Tariff & Year & $\begin{array}{l}\text { Change in energy } \\
\text { autonomy relative to } \\
\text { base cases [\%] }\end{array}$ \\
\hline \multirow[t]{18}{*}{ GMU } & \multirow[t]{3}{*}{$1 \mathrm{~h}_{\mathrm{dyn}}$} & 2015 & -0.03 \\
\hline & & 2025 & -0.09 \\
\hline & & 2035 & -0.56 \\
\hline & \multirow[t]{3}{*}{$4 \mathrm{TZ}_{\mathrm{dyn}}$} & 2015 & -0.09 \\
\hline & & 2025 & -0.12 \\
\hline & & 2035 & -0.49 \\
\hline & \multirow[t]{3}{*}{$4 \mathrm{TZ}_{\mathrm{TOU}}$} & 2015 & -0.03 \\
\hline & & 2025 & -0.10 \\
\hline & & 2035 & -0.74 \\
\hline & \multirow[t]{3}{*}{$1 h_{\text {dyn,mod,GMU }}$} & 2015 & 0.39 \\
\hline & & 2025 & 0.48 \\
\hline & & 2035 & -0.23 \\
\hline & \multirow[t]{3}{*}{$4 \mathrm{TZ}_{\mathrm{dyn}, \mathrm{mod}, \mathrm{GMU}}$} & 2015 & 0.35 \\
\hline & & 2025 & 0.39 \\
\hline & & 2035 & -0.10 \\
\hline & \multirow[t]{3}{*}{$4 \mathrm{TZ}_{\mathrm{TOU}, \mathrm{mod}, \mathrm{GMU}}$} & 2015 & 0.43 \\
\hline & & 2025 & 0.35 \\
\hline & & 2035 & -0.10 \\
\hline \multirow[t]{18}{*}{$\mathrm{CMU}$} & \multirow[t]{3}{*}{$1 \mathrm{~h}_{\mathrm{dyn}}$} & 2015 & -0.53 \\
\hline & & 2025 & -0.58 \\
\hline & & 2035 & -0.79 \\
\hline & \multirow[t]{3}{*}{$4 \mathrm{TZ}_{\mathrm{dyn}}$} & 2015 & -0.28 \\
\hline & & 2025 & -0.40 \\
\hline & & 2035 & -0.77 \\
\hline & \multirow[t]{3}{*}{$4 \mathrm{TZ}_{\mathrm{TOU}}$} & 2015 & -0.34 \\
\hline & & 2025 & -0.46 \\
\hline & & 2035 & -0.76 \\
\hline & \multirow[t]{3}{*}{$1 \mathrm{~h}_{\text {dyn,mod,GMU }}$} & 2015 & -0.22 \\
\hline & & 2025 & -0.10 \\
\hline & & 2035 & -0.55 \\
\hline & \multirow[t]{3}{*}{$4 \mathrm{TZ}_{\mathrm{dyn}, \mathrm{mod}, \mathrm{GMU}}$} & 2015 & 0.08 \\
\hline & & 2025 & -0.01 \\
\hline & & 2035 & -0.51 \\
\hline & \multirow[t]{3}{*}{$4 \mathrm{TZ}_{\mathrm{TOU}, \mathrm{mod}, \mathrm{GMU}}$} & 2015 & 0.03 \\
\hline & & 2025 & -0.15 \\
\hline & & 2035 & -0.51 \\
\hline
\end{tabular}

simultaneous consideration of municipal conditions as municipal vision, generation portfolio, customer structure.

- since the dynamic of variable electricity tariffs needs to be quite high to take advantage of the DR potential of electric household appliances, utilities need to approach their customers and communicate the benefits of more dynamic variable electricity tariffs to them.
- residential customers running a heat pump system might be approached by specific and more variable tariffs and informed about the potential benefits of installing a larger thermal buffer storage.

- in order to attract customers, any business model needs to include a mechanism that regulates the transfer of a portion of the utility gains realized due to residential DR to their customers. For instance, customers could be guaranteed certain electricity cost savings and be further rewarded for reaching specific DR patterns.

Interpreting the results also requires the inclusion of assumptions and limitations of the work. Representative customer load profiles were used as input into the model instead of calculating the customer load profiles based on information about individual electric appliances. For this reason, the specific DR characteristics of individual household appliances could have been taken into account only on an average basis. Furthermore, original variable electricity tariffs were modified based on information about the DR pattern of customers and the generation profile of both municipal energy utilities. In the performed analysis, this modification process was facilitated by the fact that there was perfect knowledge.

\section{Concluding Remarks}

The preceding analysis showed that via variable electricity tariffs energy utilities can benefit from residential DR. This is achieved by adjusting the loads of residential customers to the generation profile of their plants and by taking available DR resources into account in their trading activity. In terms of a common development of the DR business model, also customers of a municipal company are able to profit. An alignment of the business model regarding municipal conditions increases the probability of success. Additionally, DR enables the integration of fluctuating electricity generation in the respective municipality.

Regarding future research the designed tariffs could serve as input for an energy system model in which customer load profiles are calculated based on information about individual electric appliances. This would permit DR characteristics of individual appliances to be taken into account thus strengthening the validity of the results. Additionally, in a further investigation the effects of changing statutory fees and levies need to be incorporated. Beyond, the effect of DR needs to be analyzed in terms of decentralized technologies adopted by the customers. In this context, a load shifting could save costs since the load is shifted to times of energy generation and thus the self-consumption could be increased. 
Acknowledgements Computations of this work were done with resources of Leipzig University Computing Center, which were funded by German Federal Ministry of Education and Research within the project Competence Center for Scalable Data Services and Solutions Dresden/Leipzig (ScaDS, BMBF 01IS14014B).

\section{Appendix: List of Abbreviations}

CG1, Customer group 1; CG2, Customer group 2; do, Downwards; CHP, Combined heat and power; CMU, Conventional municipal utility; COP, Coefficient of power; DR, Demand response; dyn, Dynamic; el, Electrical; FT, Flat tariff; GMU, Green municipal utility; HT, High-tariff time; IRPopt, Integrated Resource Planning and Optimization; LO, Low-priced orchestrator; MIP, Mixed-integer problems; MTI, Model Confiq I; MTII, Model Confiq II; mod, Modified; NT, Low-tariff time; RTP, Real-time pricing; TOU, Timeof-use; TZ, Tariff (price) zones; th, Thermal; up, Upwards.

\section{References}

1. Albadi MH, El-Saadany EF (2008) A summary of demand response in electricity markets. Electr Power Syst Res 78(11): 1989-1996. https://doi.org/10.1016/j.epsr.2008.04.002

2. Ali M, Alahäivälä A, Malik F, Humayun M, Safdarian A, Lehtonen M (2015) A market-oriented hierarchical framework for residential demand response. Int J Electrical Power Energy Syst 69:257-263. https://doi.org/10.1016/j.ijepes.2015.01.020

3. Alizadeh M, Scaglione A, Applebaum A, Kesidis G, Levitt K (2015) Reduced-Order Load models for large populations of flexible appliances. IEEE Trans Power Syst 30(4):1758-1774. https://doi.org/10.1109/TPWRS.2014.2354345

4. Althaher S, Mancarella P, Mutale J (2015) Automated demand response from home energy management system under dynamic pricing and power and comfort constraints. IEEE Trans Smart Grid 6(4):1874-1883. https://doi.org/10.1109/TSG.2014. 2388357

5. BMWi (2015) Ein Strommarkt für die Energiewende. Bundesministerium für Wirtschaft und Energie, Berlin

6. Böttger D, Götz M, Theofilidi M, Bruckner T (2015) Control power provision with power-to-heat plants in systems with high shares of renewable energy sources-An illustrative analysis for Germany based on the use of electric boilers in district heating grids. Energy 82:157-167

7. Bruckner T, Morrison R, Handley C, Patterson M (2003) Highresolution modeling of energy-services supply systems using deeco: overview and application to policy development. Ann Oper Res 121(1):151-180

8. Bruckner T (1996) Dynamische Energie -und Emissionsoptimierung regionaler Energiesysteme: Dissertation. Publikationen der Vattenfall Europe Professur für Energiemanagement und Nachhaltigkeit

9. Bruhn J (2001) Regenerative Energiequellen und Verfahren der rationellen Energieverwendung: Synergie und Konkurrenz: Diplomarbeit am Institut für Energietechnik, Technische Universität Berlin

10. Bürger V (2009) Identifikation, Quantifizierung und Systematisierung technischer und verhaltensbedingter Stromeinsparpotenziale privater Haushalte. Westfälische wilhelms-universität Institut für Politikwissenschaft, Münster
11. Capuder T, Mancarella P (2014) Techno-economic and environmental modelling and optimization of flexible distributed multigeneration options. Energy 71:516-533. https://doi.org/10.1016/j. energy.2014.04.097

12. Destatis (2016) Wirtschaftsrechnungen - Laufende Wirtschaftsrechnungen Ausstattung privater Haushalte mit ausgewählten gebrauchsgütern Statistisches Bundesamt. Wiesbaden, Germany

13. Dütschke E, Unterländer M, Wietschel M (2012) Variable Stromtarife aus Kundensicht - Akzeptanzstudie auf Basis einer Conjoint-Analyse (No. S1/2014) Fraunhofer ISI. Karlsruhe, Germany

14. Faruqui A, Wood L (2008) Quantifying the benefits of dynamic pricing in the mass market. Edison Electric Institute, Washington, D.C.

15. Fratzscher S (2015) The future of utilities: extinction or reinvention? A transatlantic perspective. Heinrich Böll Stiftung, Washington, D.C.

16. Gärttner J (2016) Group Formation in Smart Grids: Designing Demand Response Portfolios. Dissertation

17. Geidl M (2007) Integrated Modeling and Optimization of Multicarrier Energy Systems: Dissertation an der Eidgenössische Technische Hochschule Zürich (ETH)

18. Geidl M, Andersson G (2007) Optimal power flow of multiple energy carriers. IEEE Trans Power Syst 22(1):145-155

19. Gottwalt S, Garttner J, Schmeck H, Weinhardt C (2016) Modeling and valuation of residential demand flexibility for renewable energy integration. IEEE Trans Smart Grid:1-10. https://doi.org/ 10.1109/TSG.2016.2529424

20. Götz M (2015) Langfristszenarien für den Day-Ahead Spotmarkt und Leistungspreise für Regelenergie. Fraunhofer-Zentrum für Internationales Management und Wissensökonomie (IMW), unpublished

21. Hancher L, He X, Azevedo I (2013) Shift, Not Drift: Towards Active Demand Response and Beyond. European University Institute. https://doi.org/10.2870/77210. Florenz

22. Hellwig M (2003) Entwicklung und Anwendung parametrisierter Standard-Lastprofile. P.hd. dissertation, Technische Universität München

23. Hu X, Zou C, Zhang C, Li Y (2017) Technological developments in batteries: a survey of principal roles, types, and management needs. IEEE Power and Energy Magazine 15(5):20-31. https://doi.org/10.1109/MPE.2017.2708812

24. Katz J, Balyk O, Hevia-Koch P (2016) The impact of residential demand response on the costs of a fossil-free system reserve. In: Technische Universität Dresden (ed) Proceedings of ENERDAY 2016 - 11th Confernece in Energy Economics and Technology

25. Klobasa M (2009) Dynamische Simulation eines Lastmanagements und Integration von Windenergie in ein elektrizitätsnetz ISI-schriftenreihe innovationspotenziale. Fraunhofer-IRB-Verl., Stuttgart

26. Lakić E, Artač G, Gubina AF (2015) Agent-based modeling of the demand-side system reserve provision. Electr Power Syst Res 124:85-91. https://doi.org/10.1016/j.epsr.2015.03.003

27. Meteonorm (2017). http://www.meteonorm.com/

28. Mollenhauer E, Christidis A, Tsatsaronis G (2016) Evaluation of an energy- and exergy-based generic modeling approach of combined heat and power plants. Int $\mathrm{J}$ Energy and Environ Eng 7(2):167-176. https://doi.org/10.1007/s40095-0160204-6

29. Morrison R, Wittmann T, Bruckner T (2004) Energy sustainability through representative large scale simulation - the logical and 
physical design of xeona. In: Proceedings of the International Conference on Sustainability Engineering and Science (ICSES), Auckland, New Zealand

30. Morrison R, Wittmann T, Heise J, Bruckner T (2005) Policyoriented energy system modeling with xeona. In: Proceedings of ECOS 2005 (18th International Conference on Efficiency, Cost, Optimization, Simulation and Environmental Impact of Energy Systems): Shaping our Future Energy Systems, Trondheim, Norway

31. Qureshi FA, Gorecki TT, Jones CN (2014) Model Predictive Control for Market-Based Demand Response Participation. In: IFAC Publisher (ed) 19th World Congress of the International Federation of Automatic Control

32. Richter M (2012) Utilities' business models for renewable energy: a review. Renew Sust Energ Rev 16(5):2483-2493. https://doi.org/ 10.1016/j.rser.2012.01.072

33. Scheller F, Burgenmeister B, Wellnitz P, Kondziella H, Bruckner $T$ (2016) Geschäftsmodellanalyse kommunaler Energieversorger im liberalisierten Energiemarkt - Problemformulierung und Modellentwicklung

34. Scheller F, Götz M, Burgenmeister B, Seim S, Haberland R, Kondziella H, Bruckner T (2017) Legal framework and economic feasibility of neighborhood energy storage systems. In: 10. Internationale Energiewirtschaftstagung an der TU Wien

35. Scheller F, Reichelt DG, Dienst S, Johanning S, Reichardt S, Bruckner T (2017) Effects of implementing decentralized business models at a neighborhood energy system level: A model based cross-sectoral analysis. In: 14th International Conference on the European Energy Market (EEM), pp 1-6. https://doi.org/10.1109/ EEM.2017.7981910

36. Scheller F, Johanning S, Seim S, Schuchardt K, Krone J, Haberland R, Bruckner T (2018) Legal Framework of Decentralized Energy Business Models in Germany: Challenges and Opportunities for Municipal Utilities. Zeitschrift für Energiewirtschaft. https://doi.org/10.1007/s12398-018-0227-1
37. Scott P, Thiébaux S, van den Briel M, van Hentenryck P (2013) Residential Demand Response under Uncertainty. In: Schulte C (ed) Principle and Practice of Constraint Programming - CP 2013, vol 8124, pp 645-660. https://doi.org/10.1007/978-3-64240627-0_48

38. Sensfuß F, Ragwitz M, Genoese M (2008) The merit-order effect: a detailed analysis of the price effect of renewable electricity generation on spot market prices in Germany. Energy Policy 36(8):3086-3094. https://doi.org/10.1016/j.enpol.2008.03.035

39. Setlhaolo D, Xia X, Zhang J (2014) Optimal scheduling of household appliances for demand response. Electr Power Syst Res 116:24-28. https://doi.org/10.1016/j.epsr.2014.04.012

40. Siano P (2014) Demand response and smart grids-A survey. Renew Sust Energ Rev 30:461-478. https://doi.org/10.1016/j.rser. 2013.10.022

41. Tjaden T, Bergner J, Weniger J, Quaschning V (2015) Repräsentative elektrische Lastprofile für Wohngebäude in Deutschland auf 1-sekündiger Datenbasis. Hochschule für Technik und Wirtschaft HTW Berlin

42. UBA (2011) CO2-Emissionsminderung durch Ausbau, informationstechnische Vernetzung und Netzoptimierung von Anlagen dezentraler, fluktuierender und erneuerbarer Energienutzung in Deutschland. Umweltbundesamt

43. US Department of Energy (2006) Benefits of Demand Response in Electricity Markets and Recommendations for Achieving Them. U.S. Department of Energy

44. Zeller M (2014) Analyse und Simulation von Geschäftsmodellen für Elektrizitätsvertriebsunternehmen: Untersuchungen für die Implementierung von Smart Metern: Zugl.: Berlin, Techn. Univ., Diss., 2014. Univ.-Verl. der TU Berlin, Berlin. http:// nbn-resolving.de/urn:nbn:de:kobv:83-opus4-57449

45. Zerrahn A, Schill WP (2015) On the representation of demandside management in power system models. Energy 84:840-845. https://doi.org/10.1016/j.energy.2015.03.037 